OPEN ACCESS

Edited by:

Wenkai Ren,

South China Agricultural

University, China

Reviewed by:

Senem Kamiloglu,

Uludag University, Turkey

Jie Yin,

Hunan Agricultural University, China

*Correspondence:

Sukhes Mukherjee

sukhes.biochemistry@

aiimsbhopal.edu.in

Specialty section:

This article was submitted to

Nutrition and Microbes,

a section of the journa

Frontiers in Nutrition

Received: 29 November 2020

Accepted: 06 April 2021

Published: 24 May 2021

Citation:

Ray SK and Mukherjee S (2021)

Evolving Interplay Between Dietary Polyphenols and Gut Microbiota-An Emerging Importance in Healthcare.

Front. Nutr. 8:634944.

doi: 10.3389/fnut.2021.634944

\section{Evolving Interplay Between Dietary Polyphenols and Gut Microbiota-An Emerging Importance in Healthcare}

\author{
Suman Kumar Ray ${ }^{1}$ and Sukhes Mukherjee ${ }^{2 *}$ \\ 'Independent Researcher, Bhopal, India, ${ }^{2}$ Department of Biochemistry, All India Institute of Medical Sciences, Bhopal, India
}

Polyphenols are natural plant compounds and are the most abundant antioxidants in the human diet. As the gastrointestinal tract is the primary organ provided to diet sections, the diet may be regarded as one of the essential factors in the functionality, integrity, and composition of intestinal microbiota. In the gastrointestinal tract, many polyphenols remain unabsorbed and may accumulate in the large intestine, where the intestinal microbiota are most widely metabolized. When assuming primary roles for promoting host well-being, this intestinal health environment is presented to the effect of external influences, including dietary patterns. A few different methodologies have been developed to increase solvency and transport across the gastrointestinal tract and move it to targeted intestinal regions to resolve dietary polyphenols at the low bioavailability. Polyphenols form a fascinating community among the different nutritional substances, as some of them have been found to have critical biological activities that include antioxidant, antimicrobial, or anticarcinogenic activities. Besides, it affects metabolism and immunity of the intestines and has anti-inflammatory properties. The well-being status of subjects can also benefit from the development of bioactive polyphenol-determined metabolites, although the mechanisms have not been identified. Even though the incredible variety of health-advancing activities of dietary polyphenols has been widely studied, their effect on intestinal biology adaptation, and two-way relationship between polyphenols and microbiota is still poorly understood. We focused on results of polyphenols in diet with biological activities, gut ecology, and the influence of their proportional links on human well-being and disease in this study.

Keywords: dietary polyphenols, gut microbiota, gut health environment, bioavailability, bioactivity

\section{INTRODUCTION}

Dietary polyphenols are natural plant-based compounds, including foods such as vegetables, cereals, fruits, coffee, tea, wine, etc. (1). Hydroxylated phenyl moieties define polyphenols as nothing but a large heterogeneous group of compounds. Polyphenols are usually categorized into flavonoids and non-flavonoids because of their chemical structure and complexity (including phenolic rings and substitution groups) (2). Human body perceives polyphenols as xenobiotics, and their bioavailability is moderately poor (3). Up until now, more than 8,000 polyphenols have been identified and are classified by their carbon skeleton concept: flavonoids, phenolic acids, lignans, and stilbenes (4). The intake of polyphenols varies by world topography, possibly because of the 
distinctive dietary habits of different cultures worldwide, as shown in numerous studies $(5,6)$. Micronutrient-rich essential diets with polyphenols are written in Tables 1, 2. It has been shown that phenolics and their metabolites have an affirmative influence on gut health by promoting the production of beneficial microbiota and controlling the propagation of pathogenic bacteria (8). In around 400 B.C., Hippocrates said, "death sits in the intestines" and "bad digestion is the root of all evil," indicating the essential role of the human intestine in their health and disease. In most fruits and vegetables, polyphenols, along with herbs and spices, are secondary plant metabolites $(9,10)$. In particular, due to structural complexity, polyphenols with higher molecular weight avoids absorption in the small intestine. It has been shown that in the small intestine, simply $5-10 \%$ of the overall ingested polyphenols may be absorbed (11), and how the health-advancing effects of polyphenols arise when they are inadequately ingested and commonly identified at trace levels in the systemic circulation should be considered. A complex microbial ecosystem is present in the human digestive tract, including extensive metabolic versatility, using metabolic pathways that people have not created (12). As a result, it was calculated that the advanced well-being effects of phenolics, for example, polyphenols, may possibly be detected by regulation of the composition and act of the gut microbiota, or vice versa, by the generation of bioactive microbial metabolites. Like this, the colonic microbiota plays an essential role in the breakdown of polyphenolic structures into a collection of polyphenolic metabolites of low atomic weight that can be easily absorbed and deliberately be beneficial to health (8). The inter-individual difference in the gut microbiota can prompt contrasts in bioefficacy and bioavailability of polyphenols and their metabolites, in addition to the interindividual variety in the daily admission of polyphenols. Polyphenols are often retained in the gut for more extended periods due to low absorption, where they can have a beneficial effect, especially by influencing the ecology of the intestine (13). During the most recent period, the effect of dietary polyphenols (Figure 1) on the gut ecology and mechanism underlying the impacts on intestinal and extraintestinal diseases is studied (15). In various dietary polyphenols, various researchers have found behaviors such as antioxidant, antidiabetic, anticarcinogenic, neuroprotective, anti-inflammatory, cardioprotective, antimicrobial, antiadipogenic, etc. (16-23).

\section{Polyphenols and Their Biotransformation in Gut}

For each gram of gut material, the human gut harbors an extraordinarily perplexing microbial ecosystem in groupings of 1,012 microorganisms. Every person's gut microbiota composition is unique and is influenced by a legacy acquired at the host's birth, physiological status and genotype, diet, and lifestyle $(24,25)$. A minor amount of dietary polyphenols (5-10\% of total intake) can be easily absorbed using deconjugation reactions such as deglycosylation in the small intestine (26). These polyphenolics may be exposed to large Phase I (oxidation, reduction, hydrolysis, etc.) and Phase II (conjugation)
TABLE 1 | Different types of natural polyphenols (7).

\begin{tabular}{|c|c|c|c|}
\hline \multirow{2}{*}{$\begin{array}{l}\text { Types } \\
\text { Flavonoids }\end{array}$} & \multicolumn{2}{|c|}{ Example } & \\
\hline & Isoflavonoids & \multicolumn{2}{|l|}{$\begin{array}{l}\text { Daidzein, ginlycitein } \\
\text { Genistein }\end{array}$} \\
\hline & Flavonols & \multicolumn{2}{|l|}{$\begin{array}{l}\text { Kaempfer, quercetin } \\
\text { Isorhamnetin }\end{array}$} \\
\hline & Flavones & \multicolumn{2}{|l|}{$\begin{array}{l}\text { Luteol, ainpigenin } \\
\text { Rutin }\end{array}$} \\
\hline & Flavanones & \multicolumn{2}{|c|}{$\begin{array}{l}\text { Flavanones, naringen, ninaringin } \\
\text { Hesperidin }\end{array}$} \\
\hline & Flavanols & \multicolumn{2}{|l|}{$\begin{array}{l}\text { (-)-Epicatechin } \\
\text { (+)-Gallocatechin } \\
\text { (+)-Catechin }\end{array}$} \\
\hline & Flavononols & \multicolumn{2}{|l|}{$\begin{array}{l}\text { Genist, ainstilbin } \\
\text { Engeletin }\end{array}$} \\
\hline & Anthocyanidins & \multicolumn{2}{|c|}{$\begin{array}{l}\text { Delphinid, pinelargonidin } \\
\text { Cyanidin }\end{array}$} \\
\hline \multirow[t]{8}{*}{ Non-flavonoids } & Phenolic acids & $\begin{array}{l}\text { Hydroxybenzoic } \\
\text { acid derivatives }\end{array}$ & $\begin{array}{l}\text { Gallic acid } \\
\text { Vanillic acid } \\
\text { Syringic acid } \\
\text { Ellagic acid }\end{array}$ \\
\hline & & $\begin{array}{l}\text { Hydroxycinnamic } \\
\text { acid derivatives }\end{array}$ & $\begin{array}{l}\text { Caffeic acid } \\
\text { Ferulic acid } \\
\text { Chlorogenic acid }\end{array}$ \\
\hline & & & p-Coumaric acid \\
\hline & Lignans & \multicolumn{2}{|l|}{ Pinoresinol } \\
\hline & Stilbenes & \multicolumn{2}{|l|}{ Resveratrol } \\
\hline & Tannins & Hydrolyzable tannins & $\begin{array}{l}\text { Ellagitannins } \\
\text { Gallotannins }\end{array}$ \\
\hline & & Condensed tannins & $\begin{array}{l}\text { Mono-, di-, } \\
\text { trimers } \\
4-6 \text { mers, 7-10 } \\
\text { mers, polymers }\end{array}$ \\
\hline & Coumarins & \multicolumn{2}{|c|}{ 6-Methoxymellein6-hydroxymellein } \\
\hline
\end{tabular}

biotransformations in enterocytes after absorption into the small intestine (Figure 2). Then a chain of water-soluble metabolites (methyl, glucuronide, derivatives of sulfate, etc.) rapidly release into the systemic circulation for advanced organ distribution.

Colonic microorganisms are identified to act enzymatically on excess unabsorbed polyphenols in the large intestine, successively creating metabolites of different physiological significance (27). The processing of lactones, phenolic acids, and aromatics with different side chain lengths and hydroxylation, depending on the precursor structures (phenylvaleric acids, phenylacetic acids, phenylvalerolactones, hippuric acids, phenylpropionic acids, benzoic acids, etc.) take place consecutively $(28,29)$. Besides, in the most recent decade, researchers also studied the transformation of non-flavonoid polymeric molecules called ellagitannins (or hydrolyzable tannins) (30, 31). Tannin structures are exposed to hydrolysis in the intestinal lumen, delivering free ellagic acid, after using ellagitanninrich foods, such as strawberries and raspberries, pecans, pomegranates, and oaked wines. Once in the large intestine, human colonic microflora metabolizes ellagic acid to produce 
TABLE 2 | Chemical structure of some common dietary polyphenols.

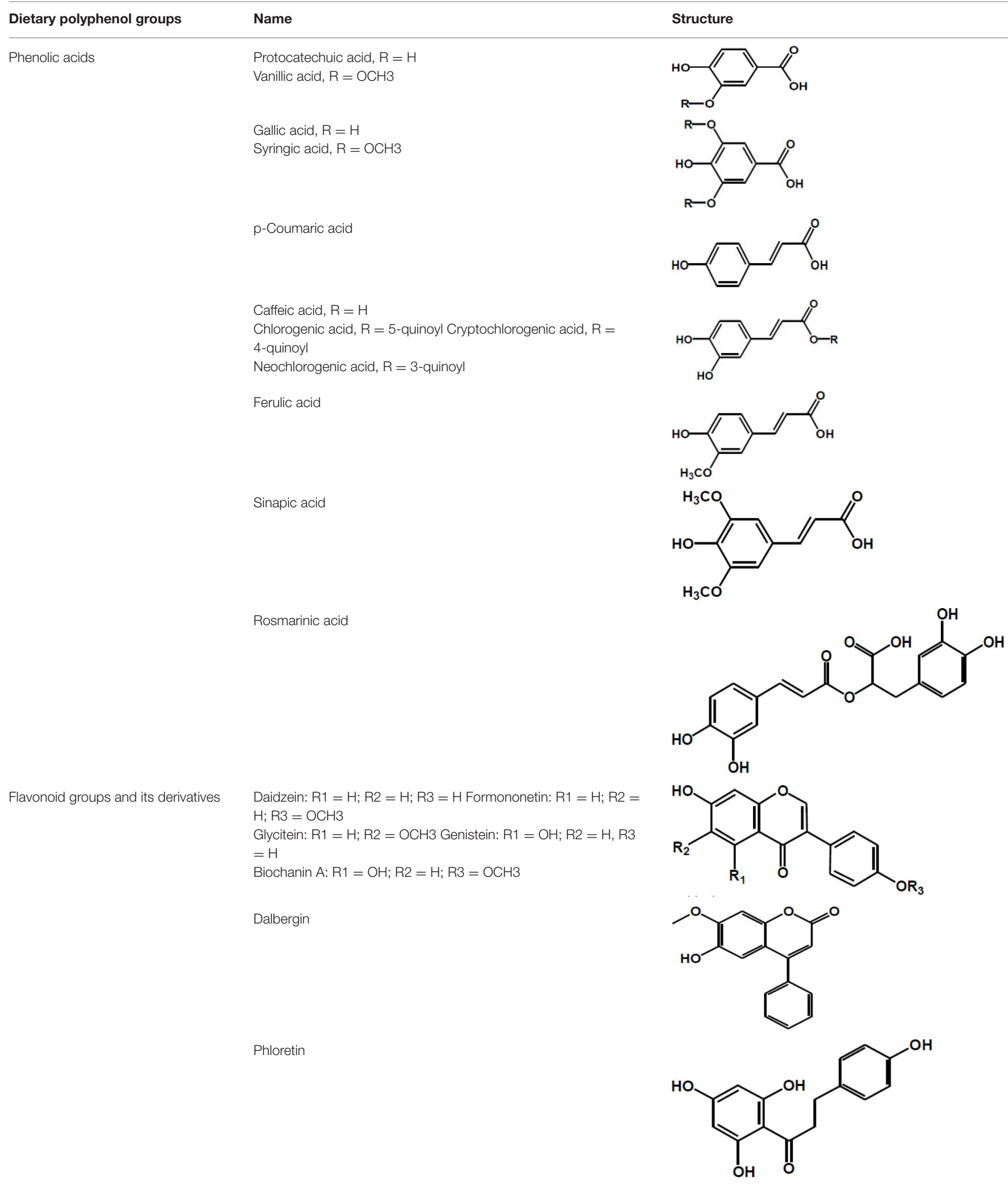

(Continued) 
TABLE 2 | Continued

Dietary polyphenol groups
Name

Xanthohumol

Apigenin $\mathrm{R}=\mathrm{H}$

Luteolin $\mathrm{R}=\mathrm{OH}$

Tangeretin $\mathrm{R}=\mathrm{H}$

Nobiletin $\mathrm{R}=\mathrm{OCH} 3$

Naringenin $\mathrm{R} 1=\mathrm{H}, \mathrm{R} 2=\mathrm{OH}$ Hesperetin $\mathrm{R} 1=\mathrm{OH}, \mathrm{R} 2=\mathrm{OCH} 3$

Kaempferol R1 = H, R2 = H Quercetin R1 = H, R2 $=\mathrm{OH}$

Myricetin $\mathrm{R} 1=\mathrm{OH}, \mathrm{R} 2=\mathrm{OH}$ Isorhamnetin $\mathrm{R} 1=\mathrm{OCH} 3, \mathrm{R} 2=\mathrm{H}$

Taxifolin

(+)-Catechin: $\mathrm{R} 1=\mathrm{R} 2=\mathrm{H}$

$(+)$-Catechin gallate: $\mathrm{R} 1=$ gallyl, $\mathrm{R} 2=\mathrm{H}$

(+)-Gallocatechin: $\mathrm{R} 1=\mathrm{H}, \mathrm{R} 2=\mathrm{OH}$

(+)-Gallocatechin gallate: $\mathrm{R} 1=$ gallyl, $\mathrm{R} 2=\mathrm{OH}$

(-)-Epicatechin: $\mathrm{R} 1=\mathrm{R} 2=\mathrm{H}$

$(-)$-Epicatechin gallate: $\mathrm{R} 1=$ gallyl, $\mathrm{R} 2=\mathrm{H}$

(-)-Epigallocatechin: R1 $=\mathrm{H}, \mathrm{R} 2=\mathrm{OH}$

(-)-Epiallocatechin gallate: $\mathrm{R} 1=$ gallyl, $\mathrm{R} 2=\mathrm{OH}$;
Structure<smiles>COc1cc(O)c(CCC(C)C)c(O)c1C(=O)CCc1ccc(O)cc1</smiles><smiles>[R]c1cc([C@H]2CC(=O)c3c(O)cc(O)cc3O2)ccc1O</smiles><smiles>[R]C1=CC(C2=C[C@H](O)c3c(OC)c(OC)c(OC)c(OC)c3O2)=CC[C@H]1OC</smiles><smiles>[R]C1=CC([C@H]2C[C@H](O)c3c(O)cc(O)cc3O2)=CC[C@H]1[R2]</smiles><smiles>[R2]c1cc([C@H]2Oc3cc(O)cc(O)c3[C@@H](O)[C@H]2O)cc([R1])c1O</smiles><smiles>O=C1c2c(O)cc(O)cc2OC(c2ccc(O)c(O)c2)C1O</smiles><smiles>[R2]O[C@H]1Cc2c(O)cc(O)cc2O[C@H]1c1cc([R2])c(O)c(O)c1</smiles><smiles>[R2]O[C@H]1Cc2c(O)cc(O)cc2O[C@H]1c1cc([R2])c(O)c(O)c1</smiles> 
TABLE 2 | Continued

Dietary polyphenol groups

Polyphenolic Amides

Other major polyphenols

\section{Name}

Procyanidins: $n>0$

Oligomeric procyanidins: $n=0-7$

Theaflavin

Anthocyanidins

Cyanidin $\mathrm{R} 1=-\mathrm{OH} ; \mathrm{R} 2=-\mathrm{H}$

Delphinidin $\mathrm{R} 1=-\mathrm{OH} ; \mathrm{R} 2=-\mathrm{OH}$ Pelargonidin $\mathrm{R} 1=-\mathrm{H} \mathrm{R} 2=-\mathrm{H}$ Malvidin R1 $=-\mathrm{OCH} 3 \mathrm{R} 2=-\mathrm{OCH} 3$ Peonidin R1 $=-\mathrm{OCH} 3 \mathrm{R} 2=$ $-\mathrm{H}$

Petunidin $\mathrm{R} 1=-\mathrm{OH} \mathrm{R} 2=-\mathrm{OCH} 3$

Avenanthramide $\mathrm{A}: \mathrm{R}=\mathrm{H}$

Avenanthramide $\mathrm{B}: \mathrm{R}=\mathrm{OCH} 3$

Avenanthramide $\mathrm{C}: \mathrm{R}=\mathrm{OH}$

Capsaicin

Dihydrocapsaicin

Resveratrol
Structure

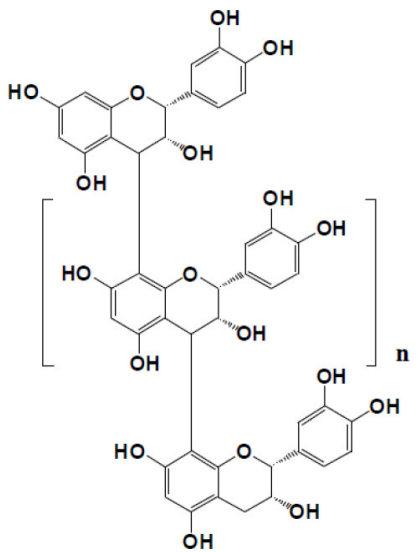<smiles>O=c1cc([C@@H]2Oc3cc(O)cc(O)c3C[C@H]2O)cc2c([C@@H]3Oc4cc(O)cc(O)c4C[C@H]3O)cc(O)c(O)c2c1O</smiles><smiles></smiles><smiles>[R]c1cc(/C=C/C(=O)Nc2ccc(O)cc2C(=O)O)ccc1O</smiles><smiles>COc1cc(CNC(=O)CCCC/C=C/C(C)C)ccc1O</smiles><smiles>COc1cc(CNC(=O)CCCCCCC(C)C)ccc1O</smiles><smiles>Oc1ccc(/C=C/c2cc(O)cc(O)c2)cc1</smiles> 
TABLE 2 | Continued



a series of derivatives known as urolithins, represented by a standard nucleus of $6 \mathrm{H}$-dibenzo[b,d]pyran-6-one and a decreasing number of phenolic hydroxyl groups (urolithin $\mathrm{D} \rightarrow$ $\mathrm{C} \rightarrow \mathrm{A} \rightarrow \mathrm{B}$ ).

Colonic bioconversion of polyphenols is mostly portrayed for flavonoids. It is a profound factor due to three principal reasons: (a) Variability has been noted in bioconversion of explicit flavonoids $(24,25,31)$, and this variability can be attributed to the individual colonic microbiota and has prompted the recognition of low to high flavonoid converters $(32,33)$; (b) Little contrasts in substitution pattern of flavonoids can initiate significant changes in colonic bioconversion $(32,34)$; (c) Dietary context of ingested polyphenols that can regulate polyphenolmicrobiota (35) interaction.

The first part of our digestive system is the mouth. When we eat polyphenols, the gullet (esophagus) passes into the stomach, and then polyphenol is transferred into the small intestine, and the intestine-from the moment it is first ingested until 


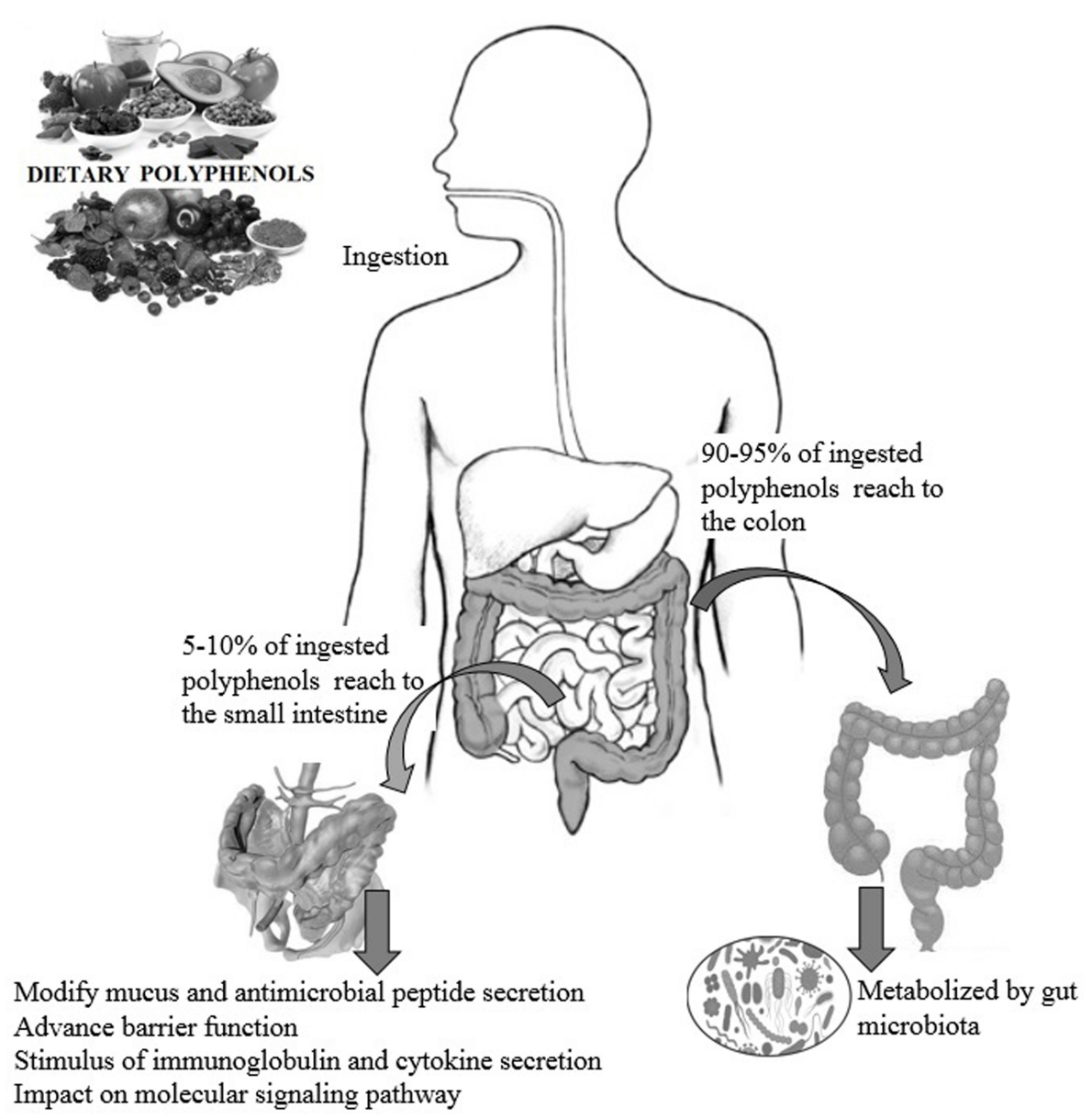

FIGURE 1 | The impact of polyphenols on gut health and the possible modes of action (14).

it is consumed by the body or passed off as feces. Although certain foods and liquids are absorbed through the lining of the stomach, the rest are immersed in the small intestine, like polyphenols. Saliva helps to lubricate food and includes enzymes that begin to digest our food chemically, including foodcontaining polyphenols. In the colon, a large $\left(\sim 4^{13}\right)$ number of microorganisms are present, where our bodies consist of around the same number of cells $\left(\sim 3^{13}\right)$. Most animals are living harmlessly; that is, they are commensals. Some are useful because they synthesize vitamins and digest polysaccharides that we do not have enzymes for (providing an estimated $10 \%$ of the calories we acquire from our food). In the small intestine, where most nutrients present in the food are ingested, digestion begins. The lumen surface of the small intestinal folds called the villi, lined by simple columnar epithelial cells called enterocytes, where every enterocyte on the cellular apical surface, have shorter microvilli (cytoplasmic membrane extensions) that increase the surface area to allow more nutrient absorption to occur.

The small intestine climate is less harsh, and microbial communities like Lactobacilli, Diphtheroid, fungus Candida, etc., may be found in the small intestine. On the other hand, a diverse and abundant microbiota is found in the large intestine essential for normal function. These microbes include Bacteriodetes (the Bacteroides and Prevotella genera, in particular) and Firmicutes. These microbes support digestion and contribute to the processing of the feces, digestive tract waste, and flatus, the gas generated by the microbial fermentation of undigested food.

\section{Effects of Dietary Polyphenols on Intonation of Gut Ecology and Cellular Environment}

The colonic microbiota could shift polyphenols to bioactive mixes that can affect the intestinal ecology and impact on host health. In vitro animal model and human studies suggest that particular dosages of experimentally selected polyphenols can alter the microbial composition of the intestine, and while some bacterial groups may be limited, others can thrive in the biome niche accessible. Phenolic blends change the gut microbiota and consequently alter the balance of bacteroids (36-38). Tzounis et al. (39) studied an in vitro model and proposed that monomers of flavan-3-ol such as $(+)$ catechin 


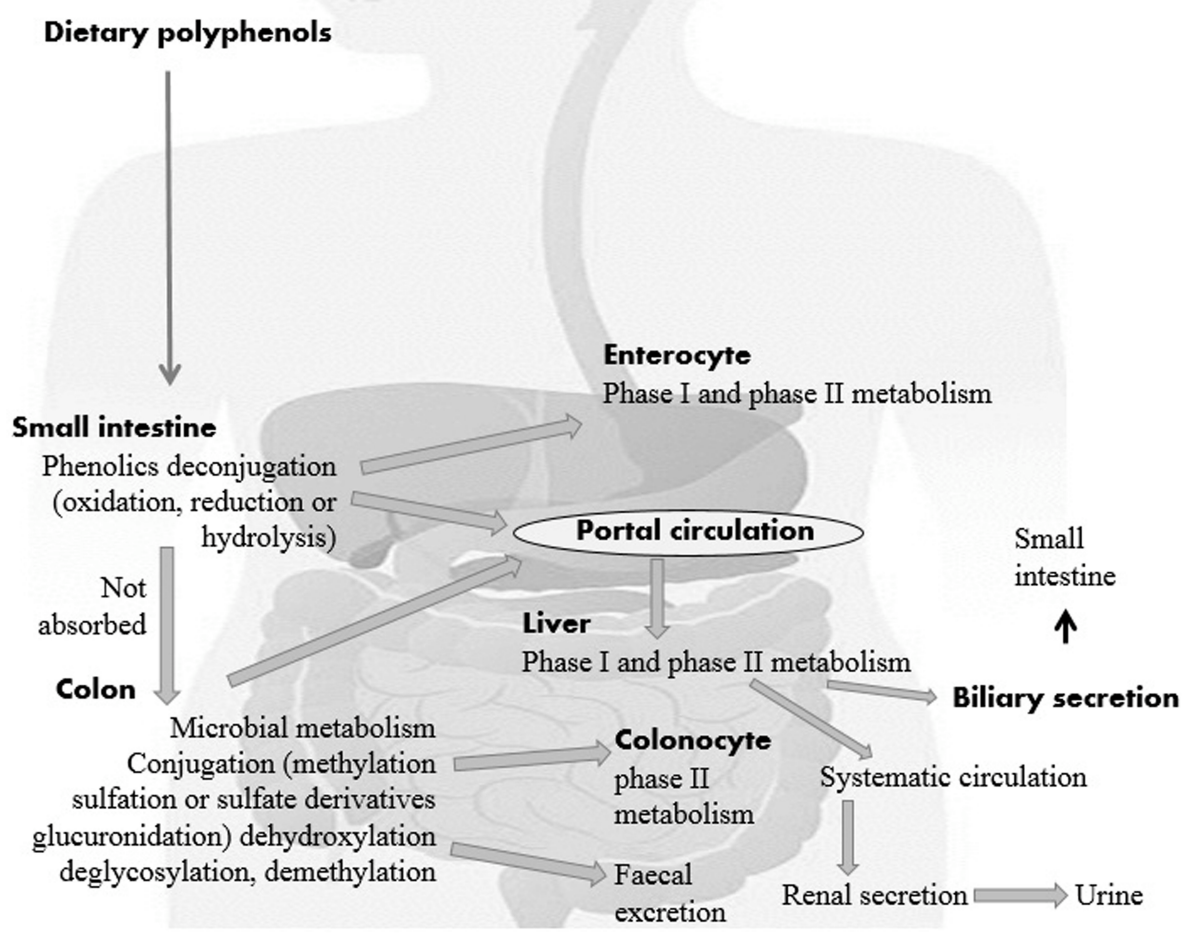

FIGURE 2 | Dietary polyphenols and its digestion.

and (-)epicatechin might be able to influence the enormous intestinal bacterial populace even in the presence of various supplements, such as starches and proteins. Yamakoshi et al. have studied that an extract rich in proanthocyanidin from grape seeds given to an adult for about 14 days has been able to increase the number of bifidobacteria significantly (40). Recent research indicates that monomeric sources rich in flavan-3-ols and flavan-3-ol, such as chocolate, green tea, and blackcurrant or grape seed extracts, can modulate the intestinal microbiota $(39,41-43)$. A human intercession analysis found that the use of red wine polyphenols substantially increased the number of bacteria groups, including Enterococcus, Prevotella, Bifidobacterium, Bacteroides, Bacteroides uniformis, Eggerthella, etc. (44). After the use of a wild blueberry drink, Vendrame et al. observed a substantial increase in the amount of Bifidobacterium, recommending a significant role for intestinal microbiota in this case (45). The role of grape seed flavan-3ols in the production of intestinal bacterial groups using in vitro experiments were analyzed by Cueva et al. (46). Although the exact mechanisms need to be clarified, preclinical and clinical evidence indicate that dietary polyphenols have prebiotic properties and antimicrobial activities against pathogenic gut microbiota, which may help with a variety of disorders. Dietary polyphenols, in particular, have been shown to modulate gut microbiota composition and function, interfering with bacterial quorum sensing, membrane permeability, and making bacteria more susceptible to xenobiotics.

\section{Overview of the Human Gut Microbiota}

Colonization and early stages of gut microbiota in the infant can be chaotic as the diversity grows over time. Interpersonal variability was found to be higher in newborn children relative to adults because of these complex shifts (47). Neonates establish a gut microbiota that takes into account the high concentration of bifidobacteria in which this dominance prevents pathogenic microorganisms from becoming colonized by competitive exclusion (48). The composition of the gut microbiota (Figure 3) in newborns changes to an adult-like form more than likely after 1 year due to the presentation of foods and other table nourishments, prompting a microbiota dominated by Bacteroidetes and Firmicutes. Finally, by $2.5-4$ years old $(47,49)$, it turns out to be absolutely like the adult microbiota, and the microbiota retain its power until old age after arriving at a developed point. Besides, older individuals have been found to have a different microbial composition compared with young adults, especially Bacteroides sp and Clostridium sp (50, 51). The role of gut microbiota in people's health and diseases is essential. The sound gut microbiota (7) has been shown to exhibit a particular role in (a) digestion of supplements, (b) 


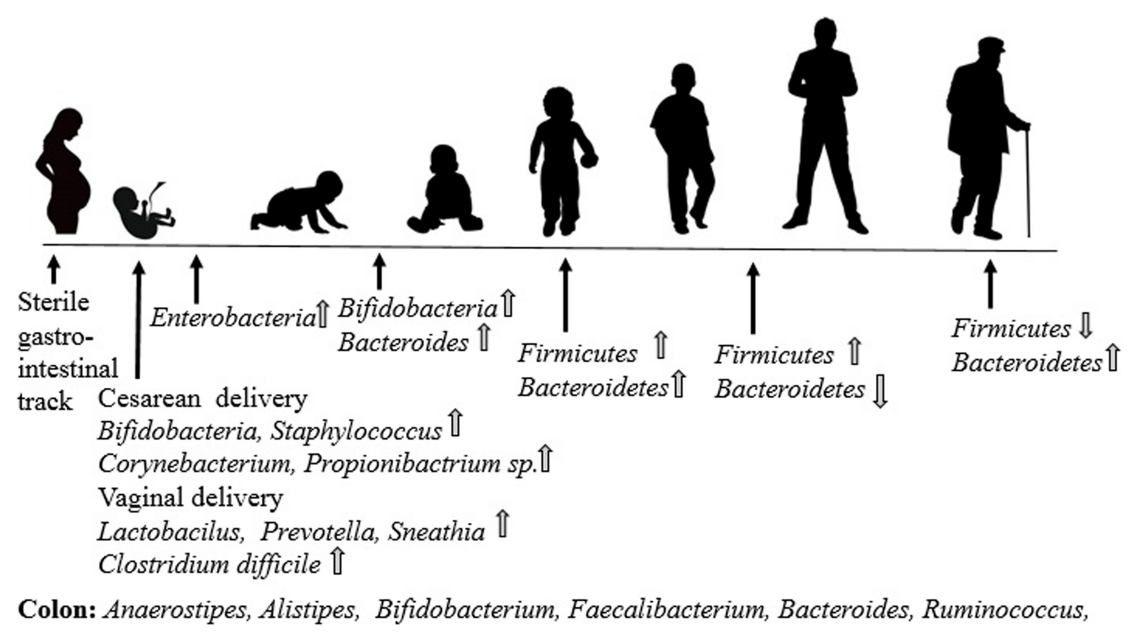

Eubacterium, Clostridium, Roseburia, Parabacteroides, Dorea etc. etc.

Small intestine: Bacteroides, Escherichia, Lactobacillus, Clostridium, Veillonella, Streptococcus etc. etc.

FIGURE 3 | Brief overview of the gut microbiota in different phases of life.

xenobiotic and drug metabolism, (c) antimicrobial activity, and (d) immunomodulation.

\section{Beneficial Effects of Dietary Polyphenols}

Dietary polyphenols are a large group of bioactive phytochemicals typically found in a wide range of vegetables, fruits, nuts, spices, and drinks, as well as in dry legumes and cereals (52). These are often associated with plant pathogen defenses, and we have a great interest in them because of their medical benefits to humans (Figure 4). They are secondary metabolites and incorporate various molecules with polyphenol structures, with more than 8,000 fundamental variations. As shown by the number of phenolic rings and their side chains or rings, they are split into separate chemical groups (53). Flavonoids have a standard diphenyl propane carbon skeleton in which a linear three-carbon chain interconnects two benzene rings. They can be split into a few subclasses that depend on the state of oxidation of the central pyran ring: flavonols, flavones, anthocyanidins, flavanones, flavonols, and isoflavones. Phenolic acids are classified into benzoic acid derivatives such as protocatechuic acid, gallic acid, and cinnamic acid derivatives, including caffeic, ferulic, and coumaric acids, are critical classes of non-flavonoids. The lignans formed by oxidative dimerization of two phenylpropane units are another essential non-flavonoid group $(54,55)$. Flavanols are the best known form of flavonoids in foodstuff, with broccoli, apples, tea, blueberries, onions, and red wine being their most lavish sources (56).

Flavanone-rich common foods are mainly citrus fruits such as lemon, grapefruit, and orange fruit (57). Flavanols are present in tea, blackberries, apples, pistachios, and almonds (58). In red fruits and vegetables (e.g., strawberry, red onion, elderberry, pomegranate, cabbage, raspberry), anthocyanins are watersoluble flavonoids present $(59,60)$. Olive oil, acerola, apricot, apple, nectar, mango, and papaya are examples of sources of flavones $(61,62)$. Isoflavones are bioactive mixtures mainly found in the legume family, including dried dates, apricot, currants, mango, plums, new coconuts, and sesame seeds $(63,64)$, although it has been shown that stilbenes are available in grapes, red wine, and berries (65). For instance, red leafy foods, blackberries, strawberries, dark radish, onions, and tea are sources of phenolic acids (57).

The role of polyphenols in counteracting different diseases, such as diabetes, obesity, neurodegenerative diseases, and cardiovascular diseases has been highlighted in numerous studies (65-70). Polyphenols are antioxidant agents also crucial to balance oxidative stress and chronic inflammation (71). Because of this, several studies have concentrated on their beneficial anti-inflammatory $(72,73)$, pain-relieving $(74)$ and antimicrobial $(54,75)$, vasodilatory (76), antiallergenic (77), anticarcinogenic (78) effects, etc.

\section{Bioavailability of Dietary Polyphenols and Impact of Gut Microbiota}

It is noteworthy that it is challenging to estimate dietary entry, and a solitary strategy cannot thoroughly evaluate dietary exposure (79), mainly when focusing on micronutrients and bioactive substances, including polyphenols. Polyphenol intake may be affected by a few different variables, for example, dietary propensities, characteristics of the population (e.g., age, gender, and social components), and geological zone (80). The consumption of polyphenols is closely related to bioavailability and bioaccessibility. In this manner, release of polyphenols from foodstuff during gastrointestinal food processing and bioaccessibility would have a major effect on bioavailability that is likely to be accessible for subsequent metabolic pathways through absorption of phenolic mixes. 


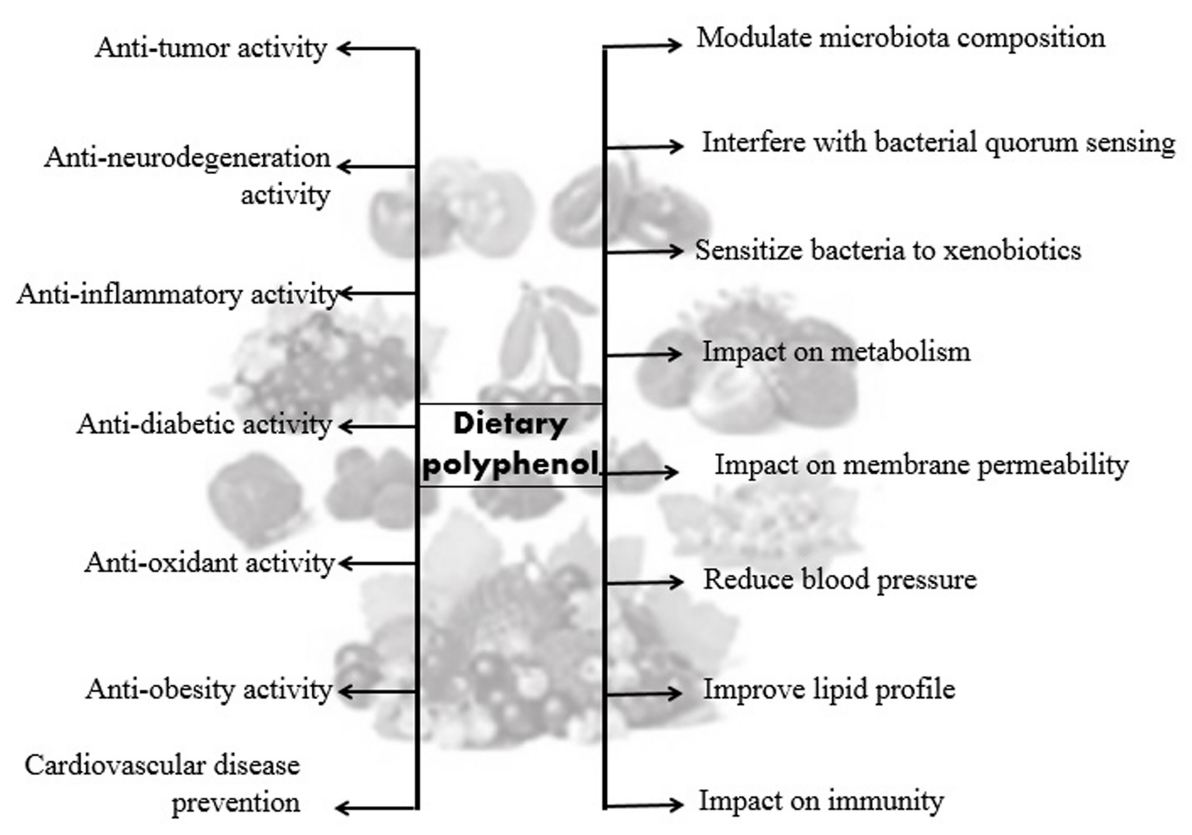

FIGURE 4 | Beneficial effects of dietary polyphenols.

The gut microbiota impacts the steadiness of dietary polyphenols through multi enzymatic responses, including sulfation, glucuronidation, deglycosylation, C ring cleavage of benzo- $\gamma$ pyrone system, decarboxylation, dehydroxylation, and hydrogenation. Most of the O-glycosides transformed to aglycones that form the structures of O-glucuronide and O-sulfate. Catabolic transformations, for example, carbon-carbon division of aromatic rings, hydrogenation, decarboxylation, and dehydroxylation of alkene moieties, are completed by gut organisms at that point. For example, quercetin 3-O-glucoside is converted by the intestinal microscopic organisms to phloroglucinol, protocatechuic acid, and 2,4,6trihydroxybenzoic acid (81-83). Curcumin is catabolized into the structural arrangements of hydrogenated, O-glucuronide, desmethyl, and O-sulfate (84). Polyphenol bioavailability involves dissolution and absorption, transmission to, and disposal of, target tissues, digestion, and excretion. It is influenced by various factors, such as food content variation, food processing, and also other factors such as genetic, microbial, dietary variables, etc. $(85,86)$. Enterocytes can be easily absorbed by aglycones, flavonols, anthocyanins, etc. Polyphenols are usually glucuronidated or possibly sulfated (stage II digestion) during intestinal absorption, while digestion at stage I (oxidation/reduction) tends to be minor (87). Besides, most native nutrient polyphenols are in the structure of glycosides (flavonols, flavones, flavonones, isoflavones, and anthocyanins), along with less frequent oligomers (proanthocyanidins), which are not absorbable in the intestinal mucosa (88).

\section{Gut Dysbiosis and Dietary Polyphenols}

Metchnikoff originally coined the word "dysbiosis" during the mid-twentieth century to represent the developments in intestinal microbes, proposing a correlation with immune homeostasis and improvement of intestinal disorders. Dysbiosis can be categorized as (89) reduction in the number of symbionts, (90) outlandish pathobiontic development, and (91) loss of diversity. Several components, including age, diet, stress, medications, and xenobiotics, are responsible for impaired gut ecology and/or dysbiosis $(89,92,93)$. The growth and evolution of human gut microbes is a case of ecological succession $(47,94)$. After an underlying stage of massive new colonization, before a steady climax network is formed, they go through progressive composition and function changes. In this case, polyphenols play a significant role. The disintegration of health including impaired salivary function, assimilation, malnutrition (95), and the intake of polyphenol by the diet are further explanations for age-related alterations in the gut ecology.

Diet is a primary modulator of the gut environment, influencing functions and thereby helping to preserve health or facilitate disease conditions (96). Breast milk, for example, contains some oligosaccharides that allow Lactobacillus and Bifidobacterium to multiply, which are predominant in the gut of the newborn child and could contribute to the development of the immune system. There is growing evidence of a relationship between dysbiosis and diseases, including inherited bowel disease (IBD), colorectal carcinoma, obesity, diabetes, etc. (97-100). The pro-inflammatory and pro-oxidative profile produced in the intestinal lumen and nearby layers is a fundamental relationship between dysbiosis and IBD progression $(101,102)$. In addition, related uremic substances resulting from intestinal microbial digestion of proteins, amino acids, and various metabolites, including mainly protein-bound phenols and indoles, and the effects of digestion of phenylalanine, tyrosine, and degradation of tryptophan, are present (103). 


\section{Polyphenols, Microbiota, and Cancer}

A few studies have related microbial metabolism of dietary polyphenols to the prevention of malignancy. In patients with and without malignant colorectal development, some studies have reported phylum-level contrasts between the gut microbiota. A few phyla are extended, while others are reduced, but it is not clear exactly how these developments impact the cancer process $(104,105)$. Studies conducted in vitro and gnotobiotic rodent models have shown that gut microbiota may turn plant lignin secoisolariciresinol diglucoside over to enterodiol and enterolactone $(31,106)$ and protect it in cancer production (Figure 5). Besides, colonization induced by polyphenol significantly decreased tumor number, size, and cell expansion, but increased apoptosis of tumor cells (107). Resveratrol's anti-inflammatory function involves proinflammatory intermediate restriction, eicosanoid union modification, and enzyme obstruction, including COX-2, NFnB, AP-1, TNF-alpha, IL6, and VEGF (vascular endothelial growth factor) (108). Biological properties, including anticancer and antioxidant function, were accounted for by ellagic acid (109). Some metabolites of intestinal polyphenols such as 3,4-dihydroxyphenylacetic acid and 3-(3,4-dihydroxyphenyl)propionic acid, quercetin metabolites, chlorogenic acid, caffeic acid, etc., can alter the enzymatic reaction involved in the detoxification of human adenoma cells from LT97. Miene et al. (110) suggested that GSTT2 upregulation and COX-2 downregulation could contribute to the chemopreventive potential of polyphenols in the intestine. Kang et al. reported that by restricting MEK1 and protein kinase such as TOPKK, caffeic acid and coffee directly repressed colon malignant growth metastasis and neoplastic cell transformation in mice (111). It has been found that flavonoids such as quercetin from apples and vegetables have anticancer effects, including cell expansion hindrance and apoptosis induction. One of these nourishments rich in polyphenols is curcumin. Polyphenol-rich foods and the preservation of high microbial diversity have been correlated with the chemopreventive effect of curcumin on the reduction of colonic tumor problems (112).

\section{Modulation of Gut Ecology by Polyphenols and Impact on Human Gut Health and Immunity}

Tzounis and his group revealed that flavonols may have been responsible for decreases in plasma C-receptive protein (CRP) levels, a blood marker of inflammation (41). As of late, QueipoOrtuño et al. (44) have found that the regular consumption of red wine polyphenols have resulted in significant reductions in blood pressure plasma levels, triglycerides, and high-density lipoprotein cholesterol. Monagas et al. (113) studied phenolic acids such as 3,4-dihydroxyphenylpropionic acid, 3-hydroxyphenylpropionic acid, 3-4-dihydroxyphenylpropionic acid, etc. They have in vitro anti-inflammatory activity, reducing the secretion of TNF- $\alpha$, IL$1 \beta$, and IL- 6 in peripheral mononuclear blood cells activated by lipopolysaccharides. Larrosa et al. examined the action and antiinflammatory ability of polyphenols and found that hydrocaffeic, dihydroxyphenylacetic, and hydroferulic acid decreased the

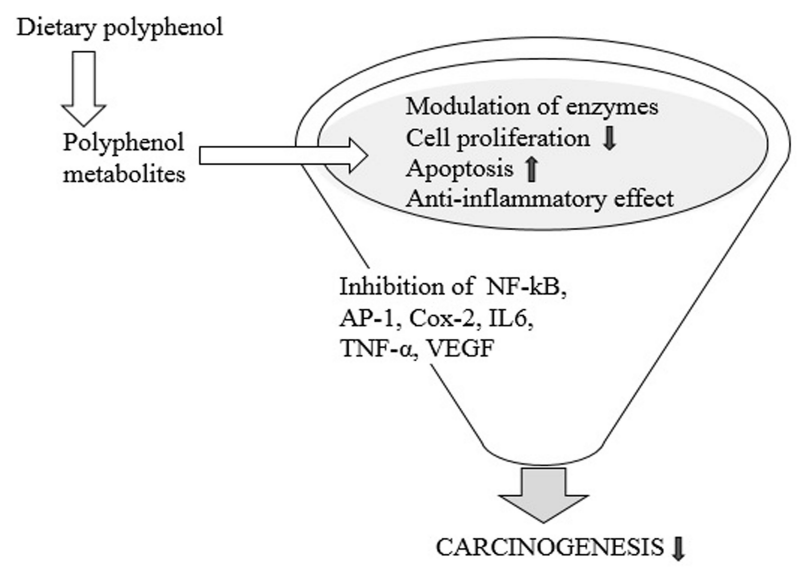

FIGURE 5 | Dietary polyphenol and carcinogenesis.

development of prostaglandin E2 in IL-1 $\beta$-mediated colon fibroblast cells (114).

Researchers have indicated that anti-inflammatory activity and intestinal inflammation could be exerted by foods containing essential hydrocaffeic acid precursors such as artichoke, chocolate, apples, and strawberries. Tucsek et al. (115) found that, for example, ferulaldehyde is used to decrease mitogen-enacted protein kinase (MAPK) activity in the final results of polyphenol degradation, thus, repressing NF- $\beta B$ activity, mitochondrial depolarization, and generation of reactive oxygen species (ROS) (115). Beloborodova et al. (116) have discovered that phenolic acids can be a biomarker of sepsis and that p-hydroxyphenylacetic acid can suppress the production of ROS in neutrophils. Resveratrol and curcumin can change the behavior of B cells as shown by a significant hindrance of lymphokine secretion, antibody production, and expansion (117). Table 3 displays preclinical and human evidence documenting the impact of polyphenols on the gut and related mechanisms.

Resveratrol deacetylates the transcriptional factor STAT3 that cannot generate orphan receptor-gamma $t(\mathrm{ROR} \gamma \mathrm{t})$ related to retinoic acid, which is a transcriptional factor that is essential for lymphocyte differentiation cycle (154). Another anticipated feature of polyphenol in the gut's adaptive immune response may be its activity on Treg cells, demonstrating a fundamental role in recalling and suppressing autoimmunity for immune tolerance. The secretion of IFN $\gamma$, tumor necrosis factor alpha $(\mathrm{TNF} \alpha)$, and IL-6 and colonic invasion of $\mathrm{CD}^{+} \mathrm{T}$ cells, $\mathrm{F} 4 / 80^{+}$macrophages, and $\mathrm{CD} 177^{+}$neutrophils are essentially suppressed by chlorogenic acid employing methods to block the active NF-B signaling pathway (155). The activity of polyphenols involves numerous signaling pathways such as MAPK, ERK1/2, p38, NF-kB, JNK, etc. $(156,157)$.

\section{Strategies to Improve Efficiency of Dietary Polyphenols in Gut}

Low bioavailability illustrates the biggest drawback of polyphenols, which undermines the medical advantages imaginable. Among various remedial methodologies, multiple 
TABLE 3 | Preclinical and human studies with dietary polyphenols on the gut and associated mechanisms (118).

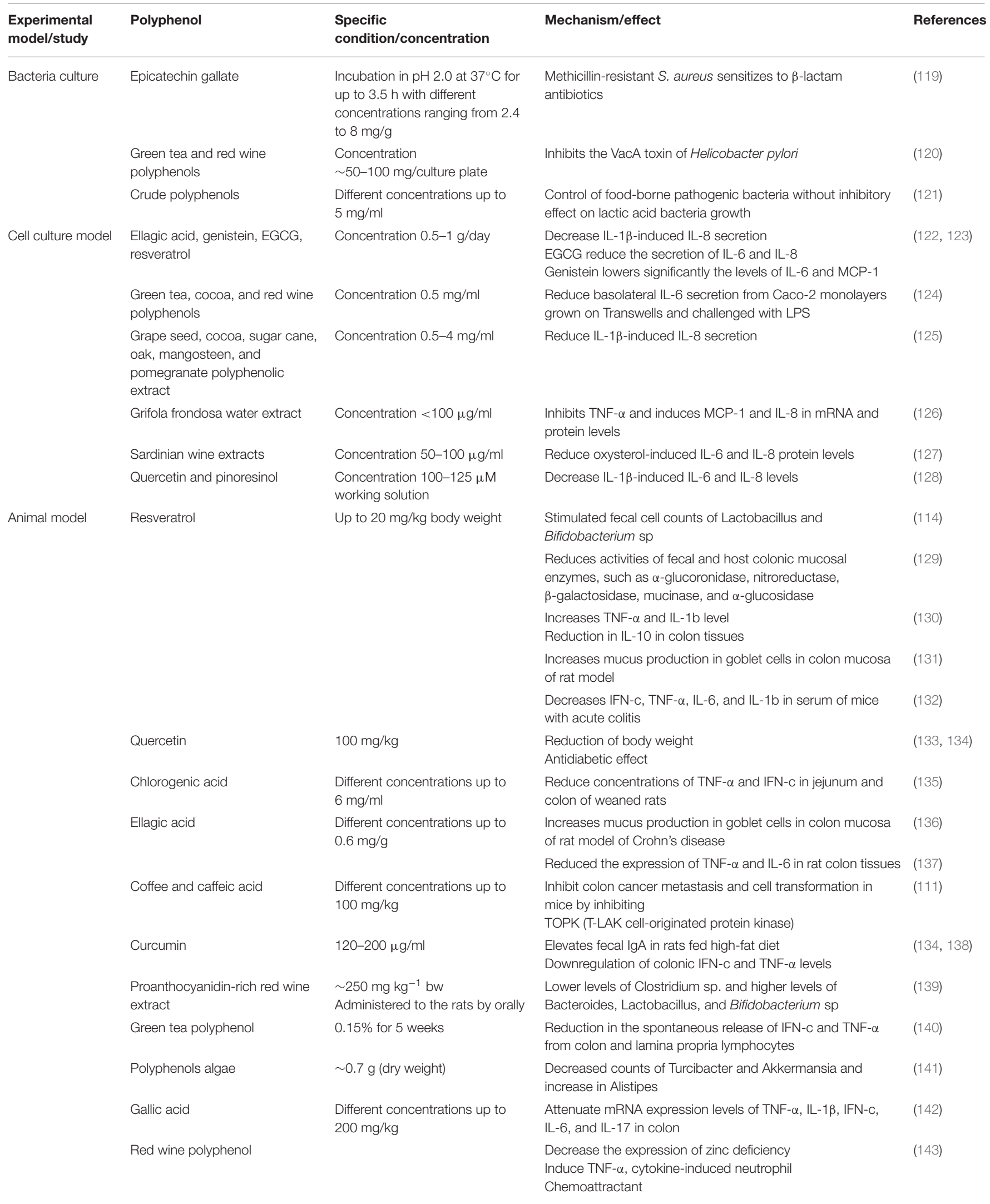


TABLE 3 | Continued

\begin{tabular}{|c|c|c|c|c|}
\hline $\begin{array}{l}\text { Experimental } \\
\text { model/study }\end{array}$ & Polyphenol & $\begin{array}{l}\text { Specific } \\
\text { condition/concentration }\end{array}$ & Mechanism/effect & References \\
\hline & $\begin{array}{l}\text { Chinese propolis, Brazilian } \\
\text { propolis }\end{array}$ & $\begin{array}{l}100-200 \mathrm{mg} / \mathrm{kg} / \mathrm{twice} \text { daily for } \\
12 \text { weeks }\end{array}$ & $\begin{array}{l}\text { Modulation of gut microflora composition } \\
\text { Reduction of Bacteroides sp. }\end{array}$ & (144) \\
\hline & Piceatannol & & Increases in IL-1 $\beta$, IL-6, and TNF- $\alpha$ in colon & $(145)$ \\
\hline & Polyphenols (from fungi) & & Modulation of gut microflora composition & $(118)$ \\
\hline & $\begin{array}{l}\text { Cocoa containing a total } \\
\text { polyphenol }\end{array}$ & & $\begin{array}{l}\text { Reduces IgA and IL-6 in Peyer's patches and mesenteric } \\
\text { lymph nodes }\end{array}$ & $(146,147)$ \\
\hline & Prunella vulgaris honey & $\sim 20 \mu \mathrm{g} / \mathrm{ml}$ working concentration & $\begin{array}{l}\text { Modulation of gut microflora composition, with increased } \\
\text { Bacteroidetes/Firmicutes ratio } \\
\text { Restoration of Lactobacillus sp. populations }\end{array}$ & $(148)$ \\
\hline & Pomegranate polyphenols & $\begin{array}{l}\sim 70 \mathrm{mg} / \mathrm{ml} \text { working } \\
\text { concentration }\end{array}$ & $\begin{array}{l}\text { Reduce TNF- } \alpha \text { and IL- } 1 \beta \text { mRNA, and TNF- } \alpha, \text { IL-1 } \beta \text {, and IL- } 6 \\
\text { protein levels in intestinal mucosa }\end{array}$ & (149) \\
\hline & $\begin{array}{l}\text { Aronia polyphenol, haskap } \\
\text { polyphenol, bilberry polyphenol }\end{array}$ & & Elevate the amount of fecal IgA in rats & (150) \\
\hline & Red wine & $\begin{array}{l}150 \mathrm{ml} / \text { day women } \\
300 \mathrm{ml} / \text { day men }\end{array}$ & $\begin{array}{l}\text { Regular consumption results in a blood pressure reduction, } \\
\text { increased lipid profile, and a decrease of uric acid } \\
\text { Increase the proliferation of Bacteroides sp. }\end{array}$ & (152) \\
\hline & Green tea, fruits, vinegar wine & $\begin{array}{l}\text { 700-900 ml/day green tea } \\
\text { But not excessive }\end{array}$ & $\begin{array}{l}\text { Impact of weight reduction along with alteration in microflora } \\
\text { of the gut }\end{array}$ & $(153)$ \\
\hline & Cocoa-derived flavanols & $\begin{array}{l}\text { Wide range of concentrations } \\
\text { depending upon health status }\end{array}$ & $\begin{array}{l}\text { Increase growth and proliferation of Bifidobacterium sp. and } \\
\text { Lactobacillus sp. }\end{array}$ & (41) \\
\hline & $\begin{array}{l}\text { (+)Catechin and } \\
(-) \text { Epicatechin }\end{array}$ & $3 \mathrm{~g} /$ day & $\begin{array}{l}\text { Inhibition of Clostridium histolyticum growth } \\
\text { Growth of Lactobacillus sp. and Bifidobacterium sp. } \\
\text { remained unchanged }\end{array}$ & (39) \\
\hline & $\begin{array}{l}\text { Proanthocyanidin-rich grape } \\
\text { extract }\end{array}$ & $100-300 \mathrm{mg} /$ day & Important rise in bifidobacterial numbers & (40) \\
\hline
\end{tabular}

procedures have recently been proposed to overcome this challenge. Several methods have been suggested to manipulate physiological changes in the gut, such as $\mathrm{pH}$-delicate delivery system, protein linkers, osmotic-controlled, prodrugs, etc. (158). To boost their digestive stability and intestinal transport, Chung et al. (159) used two separate forms of hydroxyl propyl methylcellulose phthalate (HPMCP), namely, $\mathrm{S}$ and $\mathrm{L}$, to cover green tea catechins. Bioavailability was investigated in combination with Caco-2 cells in an in vitro gastrointestinal model concerning green tea catechins alone; the intestinal transport rate of L-HPMCP demonstrated an expansion of 3.47 times. In the presence of PLGA in a 2:1 weight ratio, Eudragit S100 (ERS100) was also used to acquire curcumin drug delivery microparticles as anti-inflammatory agents in colitis tissues. Carrier showed the efficacy of curcumin on ulcerative colitis (160). Resveratrol fibroin nanoparticles showed high efficacy in reducing myeloperoxidase activity in repressing TNF, IL-1, IL-6, and IL-12 expression. This technique is, therefore, an attractive framework for the controlled arrival of resveratrol in intestinal inflammation by all accounts (161). Similarly, numerous polyphenols and anthocyanins were absorbed by the microcapsules, which protected them from difficult gastrointestinal conditions. Understanding of the polyphenol components may be studied by controlling microbial arrangement in the gut in collaboration with various probiotic strains. It would enable the enhancement of innovative ways to prevent and treat targeted microbiota diseases and epigenetics and metabolomics discoveries, contributing to tailored drug delivery and nutraceuticals.

\section{CONCLUSION REMARKS AND FUTURE PERSPECTIVES}

The consumption of polyphenols and their bioavailability decides their health effects. Concentration of plasma of these discrete polyphenolic molecules rarely reaches micromolar levels, considering the high abundance of polyphenols in our diet. Up till now, numerous studies have been performed to know the biotransformation by colonic microflora of polyphenols and to classify the microorganisms responsible. It is clear that dietary polyphenols and their metabolites, by promoting the growth of beneficial bacteria and inhibiting pathogenic bacteria, exerting prebiotic-like effects, contribute to preserving gut health through the regulation of the gut microbial balance. Alternatively, inflection of gut microbiota composition by phenolic compounds has also been assessed to make reciprocal interactions between gut microbiota and phenolic compounds. 
In conclusion, it will be crucial to use the recent developments in high-throughput transcriptomic, metagenomic, and proteomic approaches to gain a deeper understanding of the interaction between the gut microbiota and dietary polyphenols to identify the genes and microorganisms involved in polyphenol metabolism and, thus, to elucidate the implications of the relationships between polyphenols. Several factors, including unhealthy dietary patterns, can contribute to the disturbance of the balance of microbiota (dysbiosis) associated with gastrointestinal diseases (including IBD) and extraintestinal metabolic disorders, such as obesity and diabetes. Polyphenols are found in a wide variety of healthy foods, including vegetables, fruits, etc. Proof from preclinical and clinical studies indicate prebiotic effects on polyphenols. The positive effects

\section{REFERENCES}

1. Puupponen-Pimiä R, Aura AM, Oksman-Caldentey KM, Myllärinen P, Saarela M, Mattila-Sandholm T, et al. Development of functional ingredients for gut health. Trends Food Sci Tech. (2002) 13:3-11. doi: 10.1016/S0924-2244(02)00020-1

2. Neveu V, Perez-Jiménez J, Vos F, Crespy V, du Chaffaut L, Mennen L, et al. Phenol- Explorer: an online comprehensive database on polyphenol contents in foods. Database. (2010) 2010:bap024. doi: 10.1093/database/bap024

3. Landete, JM. Updated knowledge about polyphenols: functions, bioavailability, metabolism, and health. Crit Rev Food Sci Nutr. (2012) 52:936-48. doi: 10.1080/10408398.2010.513779

4. Guo W, Kong E, Meydani M. Dietary polyphenols, inflammation, and cancer. Nutr Cancer. (2009) 61:807-10. doi: 10.1080/01635580903285098

5. Taguchi C, Kishimoto Y, Fukushima Y, Saita E, Tanaka M, Takahashi Y, et al. Dietary polyphenol intake estimated by 7-day dietary records among Japanese male workers: evaluation of the within-and between-individual variation. J Nutr Sci Vitaminol. (2017) 63:180-5. doi: 10.3177/jnsv.63.180

6. Zamora-Ros R, Knaze V, Rothwell JA, Hemon B, Moskal A, Overvad K, et al. Dietary polyphenol intake in Europe: the European prospective investigation into cancer and nutrition (EPIC) study. Eur J Nutr. (2016) 55:1359-75. doi: 10.1007/s00394-015-0950-x

7. Catalkaya G, Venema K, Lucini L, Rocchetti G, Delmas D, Daglia M, et al. Interaction of dietary polyphenols and gut microbiota: microbial metabolism of polyphenols, influence on the gut microbiota, and implications on host health. Food Front. (2020) 1:109-33. doi: 10.1002/fft2.25

8. Cardona F, Andrés-Lacueva C, Tulipani S, Tinahones FJ, Queipo-Ortuño MI. Benefits of polyphenols on gutmicrobiota and implications in human health. J Nutr Biochem. (2013) 24:1415-22. doi: 10.1016/j.jnutbio.2013.05.001

9. Zhang H, Tsao R. Dietary polyphenols, oxidative stress and antioxidant and anti-inflammatory effects. Curr Opin Food Sci. (2016) 8:33-42. doi: 10.1016/j.cofs.2016.02.002

10. Guldiken B, Ozkan G, Catalkaya G, Ceylan FD, Yalcinkaya IE, Capanoglu E. Phytochemicals of herbs and spices: health versus toxicological effects. Food Chem Toxicol. (2018) 119:37-49. doi: 10.1016/j.fct.2018.05.050

11. Gowd V, Karim N, Shishir MRI, Xie L, Chen W. Dietary polyphenols to combat the metabolic diseases via altering gut microbiota. Trends Food Sci Technol. (2019) 93:81-93. doi: 10.1016/j.tifs.2019.09.005

12. Qin J, Li R, Raes J, Arumugam M, Burgdorf KS, Manichanh C, et al. A human gut microbial gene catalogue established by metagenomic sequencing. Nature. (2010) 464:59-65. doi: 10.1038/nature08821

13. Duda-Chodak A, Tarko T, Satora P, Sroka P. Interaction of dietary compounds, especially polyphenols, with the intestinal microbiota: a review. Eur J Nutr. (2015) 54:325-41. doi: 10.1007/s00394-015-0852-y

14. Murphy L, Wan Y, V Anna Co, El-Nezami H. Dietary polyphenol impact on gut health and microbiota. Crit Rev Food Sci Nutr. (2020) 61:690-711. doi: $10.1080 / 10408398.2020 .1744512$ of polyphenol-rich plants, their extracts, and even individual compounds on gut health, which can be used as an alternative method for preventing or treating various diseases linked to oxidative stress and inflammation, are increasingly being seen and emphasized in the literature. Future studies should also consider their metabolites' behavior, which may influence the therapeutic outcome of health and disease, given that polyphenols may undergo significant changes during digestion and absorption and that the changed forms may have different biological properties and forces.

\section{AUTHOR CONTRIBUTIONS}

SKR and SM: paper writing, concept, and editing.

15. Kawabata K, Yoshioka Y, Terao J. Role of intestinal microbiota in the bioavailability and physiological functions of dietary polyphenols. Molecules. (2019) 24:370. doi: 10.3390/molecules24020370

16. Wu T, Grootaert C, Pitart J, Vidovic NK, Kamiloglu S, Possemiers S, et al. Aronia (Aronia melanocarpa) polyphenols modulate the microbial community in a simulator of the human intestinal microbial ecosystem (SHIME) and decrease secretion of proinflammatory markers in a Caco2/endothelial cell coculture model. Mol Nutr Food Res. (2018) 62:e1800607. doi: 10.1002/mnfr.201800607

17. Mandel S, Youdim MB. Catechin polyphenols: neurodegeneration and neuroprotection in neurodegenerative diseases. Free Radic Biol Med. (2004) 37:304-17. doi: 10.1016/j.freeradbiomed.2004.04.012

18. Middleton E, Kandaswami C, Theoharides TC. The effects of plant flavonoids on mammalian cells: implications for inflammation, heart disease, and cancer. Pharmacol Rev. (2000) 52:673-751.

19. Sabu M, Smitha K, Kuttan R. Anti-diabetic activity of green tea polyphenols and their role in reducing oxidative stress in experimental diabetes. $J$ Ethnopharmacol. (2002) 83:109-16. doi: 10.1016/S0378-8741(02)00217-9

20. Tipoe GL, Leung TM, Hung MW, Fung ML. Green tea polyphenols as an anti-oxidant and anti-inflammatory agent for cardiovascular protection. Cardiovasc Hematol Disord Drug Targets. (2007) 7:135-44. doi: $10.2174 / 187152907780830905$

21. Umeno A, Horie M, Murotomi K, Nakajima Y, Yoshida Y. Antioxidative and antidiabetic effects of natural polyphenols and isoflavones. Molecules. (2016) 21:708. doi: 10.3390/molecules21060708

22. Chiva-Blanch G, Visioli F. Polyphenols and health: moving beyond antioxidants. J Berry Res. (2012) 2:63-71. doi: 10.3233/JBR-2012-028

23. Ozdal T, Sela DA, Xiao J, Boyacioglu D, Chen F, Capanoglu E. The reciprocal interactions between polyphenols and gut microbiota and effects on bioaccessibility. Nutrients. (2016) 8:78. doi: 10.3390/nu8020078

24. Turnbaugh PJ, Hamady M, Yatsunenko T, Cantarel BL, Duncan A, Ley $\mathrm{RE}$, et al. A core gut microbiome in obese and lean twins. Nature. (2008) 457:480-4. doi: 10.1038/nature07540

25. Zoetendal EG, Vaughan EE, deVos WM. A microbial world within us. $\mathrm{Mol}$ Microbiol. (2006) 59:1639-50. doi: 10.1111/j.1365-2958.2006.05056.x

26. Manach C, Williamson G, Morand C, Scalbert A, Remesy C. Bioavailability and bioefficacy of polyphenols in humans. Review of 97 bioavailability studies. Am J Clin Nutr. (2005) 81:230S-42S doi: 10.1093/ajcn/81.1.230S

27. Bowey E, Adlercreutz H, Rowland I. Metabolism of isoflavones and lignans by the gut microflora: a study in germ-free and human flora associated rats. Food Chem Toxicol. (2003) 41:631-6. doi: 10.1016/S0278-6915(02)00324-1

28. Saura-Calixto F, Serrano J, Goñi I. Intake and bioaccessibility of total polyphenols in a whole diet. Food Chem. (2007) 101:492-01. doi: 10.1016/j.foodchem.2006.02.006

29. Manach C, Scalbert A, Morand C, Remesy C, Jimenez L. Polyphenols: food sources and bioavailability. Am J Clin Nutr. (2004) 79:727-47. doi: $10.1093 /$ ajcn/79.5.727 
30. Larrosa M, García-Conesa MT, Espín JC, Tomás-Barberán FA. Ellagitannins, ellagic acid and vascular health. Mol Aspects Med. (2010) 31:513-39. doi: 10.1016/j.mam.2010.09.005

31. Blaut M, Clavel T. Metabolic diversity of the intestinal microbiota: implications for health and disease. J Nutr. (2007) 137(3 Suppl. 2):751S-55S. doi: 10.1093/jn/137.3.751S

32. Simons AL, Renouf M, Hendrich S, Murphy PA. Human gut microbial degradation of flavonoids: structure-function relationships. J Agric Food Chem. (2005) 53:4258-63. doi: 10.1021/jf0500177

33. Erlund I. Review of the flavonoids quercetin, hesperetin, and naringenin. Dietary sources, bioactivities, bioavailability, and epidemiology. Nutr Res. (2004) 24:851-74. doi: 10.1016/j.nutres.2004.07.005

34. Schoefer L, Mohan R, Braune A, Birringer M, Blaut M. Anaerobic C-ring cleavage of genistein and daidzein by Eubacterium ramulus. FEMS Microbiol Lett. (2002) 208:197-202. doi: 10.1111/j.1574-6968.2002.tb11081.x

35. Roowi S, Mullen W, Edwards CA, Crozier A. Yoghurt impacts on the excretion of phenolic acids derived from colonic breakdown of orange juice flavanones in humans. Mol Nutr Food Res. (2009) 53(Suppl. 1):S68-75. doi: 10.1002/mnfr.200800287

36. Stoupi S, Williamson G, Drynan JW, Barron D, Clifford MN. A comparison of the in vitro biotransformation of (-)-epicatechin and procyanidin B2 by human faecal microbiota. Mol Nutr Food Res. (2010) 54:747-59. doi: 10.1002/mnfr.200900123

37. Lee HC, Jenner AM, Low CS, Lee YK. Effect of tea phenolics and their aromatic fecal bacterial metabolites on intestinal microbiota. Res Microbiol. (2006) 157:876-84. doi: 10.1016/j.resmic.2006.07.004

38. Hervert-Hernandez D, Pintado C, Rotger R, Goni I. Stimulatory role of grape pomace polyphenols on Lactobacillus acidophilus growth. Int J Food Microbiol. (2009) 136:119-22. doi: 10.1016/j.ijfoodmicro.2009.09.016

39. Tzonuis X, Vulevic J, Kuhnle GG, George T, Leonczak J, Gibson GR, et al. Flavanol monomer-induced changes to thehumanfaecalmicroflora. Br JNutr. (2008) 99:782-92. doi: 10.1017/S0007114507853384

40. Yamakoshi J, Tokutake S, Kikuchi M. Effect of proanthocyanidin- rich extract from grape seeds on human fecal flora andfecal odor. Microb Ecol Health Dis. (2001) 13:25-31. doi: 10.1080/089106001750071672

41. Tzounis X, Rodriguez-Mateos A, Vulevic J, Gibson GR, Kwik-Uribe C, Spencer JP. Prebiotic evaluation of cocoa-derived flavanols in healthy humans by using a randomized, controlled, double-blind, crossover intervention study. Am J Clin Nutr. (2011) 93:62-72. doi: 10.3945/ajen.110.000075

42. Molan AL, Liu Z, Kruger M. The ability of blackcurrant extracts to positively modulate key markers of gastrointestinal function in rats. World J Microbiol Biotechnol. (2011) 26:1735-43. doi: 10.1007/s11274-010-0352-4

43. Viveros A, Chamorro S, Pizarro M, Arija I, Centeno C, Brenes A. Effects of dietary polyphenol-rich grape products on intestinal microflora and gut morphology in broiler chicks. Poult Sci. (2011) 90:566-78. doi: 10.3382/ps.2010-00889

44. Queipo-Ortuño MI, Boto-Ordóñez M, Murri M, Gomez-Zumaquero JM, Clemente-Postigo M, Estruch R, et al. Influence of red wine polyphenols and ethanol on the gut microbiota ecology and biochemical biomarkers. Am J Clin Nutr. (2012) 95:1323-34. doi: 10.3945/ajcn.111.027847

45. Vendrame S, Guglielmetti S, Riso P, Arioli S, Klimis-Zacas D, Porrini M. Six-week consumption of a wild blueberry powder drink increases bifidobacteria in the human gut. J Agric Food Chem. (2011) 59:12815-20. doi: 10.1021/jf2028686

46. Cueva C, Sánchez-Patán F, Monagas M, Walton GE, Gibson GR, Martín-Álvarez PJ, et al. In vitro fermentation of grape seed flavan-3ol fractions by human faecal microbiota: changes in microbial groups and phenolic metabolites. FEMS Microbiol Ecol. (2012) 83:792-805. doi: 10.1111/1574-6941.12037

47. Koenig JE, Spor A, Scalfone N, Fricker AD, Stombaugh J, Knight R, et al. Succession of microbial consortia in the developing infant gut microbiome. Proc Natl Acad Sci USA. (2011) 108(Suppl. 1):4578-85. doi: 10.1073/pnas.1000081107

48. Sela DA, Chapman J, Adeuya A, Kim JH, Chen F, Whitehead TR, et al. The genome sequence of Bifidobacterium longum subsp infantis reveals adaptations for milk utilization within the infant microbiome. Proc Natl Acad Sci USA. (2008) 105:18964-9. doi: 10.1073/pnas.0809584105
49. Palmer C, Bik EM, DiGiulio DB, Relman DA, Brown PO. Development of the human infant intestinal microbiota. PLoS Biol. (2007) 5:1556-73. doi: 10.1371/journal.pbio.0050177

50. Claesson MJ, Cusack S, O’Sullivan O, Greene-Diniz R, de Weerd H, Flannery E, et al. Composition, variability, and temporal stability of the intestinal microbiota of the elderly. Proc Natl Acad Sci USA. (2011) 108:4586-91. doi: $10.1073 /$ pnas. 1000097107

51. Clemente JC, Ursell LK, Parfrey LW, Knight R. The impact of the gut microbiota on human health: an integrative view. Cell. (2012) 148:1258-70. doi: 10.1016/j.cell.2012.01.035

52. Vinson JA, Su X, Zubik L, Bose P. Phenol antioxidant quantity and quality in foods: fruits. J Agric Food Chem. (2001) 49:5315-21. doi: 10.1021/jf0009293

53. Kabera JN, Semana E, Mussa AR, He X. Plant secondary metabolites: biosynthesis, classification, function and pharmacological properties. $J$ Pharm Pharmacol. (2014) 2:377-92.

54. Daglia M. Polyphenols as antimicrobial agents. Curr Opin Biotechnol. (2012) 23:174-81. doi: 10.1016/j.copbio.2011.08.007

55. Quideau S, Deffieux D, Douat-Casassus C, Pouységu L. Plant polyphenols: chemical properties, biological activities, and synthesis. Angew Chem Int Ed. (2011) 50:586-21. doi: 10.1002/anie.201000044

56. Hollman PCH, Katan MB. Dietary flavonoids: intake, health effects and bioavailability. Food Chem Toxicol. (1999) 37:937-42. doi: 10.1016/S0278-6915(99)00079-4

57. Tomas-Barberan F, Clifford M. Dietary hydroxybenzoic acid derivatives and their possible role in health protection. J Sci Food Agric. (2000) 80:1024-32. doi: 10.1002/(SICI)1097-0010(20000515)80:7<1024::AIDJSFA567>3.0.CO;2-S

58. Bhagwat S, Haytowitz DB, Holden JM. USDA Database for the Flavonoid Content of Selected Foods. Beltsville, MD: US Department of Agriculture. (2014).

59. Prasain JK, Grubbs C, Barnes S. Cranberry anti-cancer compounds and their uptake and metabolism: an updated review. J Berry Res. (2020) 10:1-10. doi: 10.3233/JBR-180370

60. Weber F, Larsen LR. Influence of fruit juice processing on anthocyanin stability. Food Res Int. (2017) 100:354-65. doi: 10.1016/j.foodres.2017.06.033

61. Bataglion GA, da Silva FM, Eberlin MN, Koolen HH. Determination of the phenolic composition from Brazilian tropical fruits by UHPLC-MS/MS. Food Chem. (2015) 180:280-7. doi: 10.1016/j.foodchem.2015.02.059

62. Siriamornpun S, Kaewseejan N. Quality, bioactive compounds and antioxidant capacity of selected climacteric fruits with relation to their maturity. Sci Hortic. (2017) 221:33-42. doi: 10.1016/j.scienta.2017.04.020

63. Bustamante-Rangel M, Delgado-Zamarreño MM, Pérez-Martín L, Rodríguez-Gonzalo E, Domínguez-Álvarez J. Analysis of isoflavones in foods. Compr Rev Food Sci Food Saf. (2018) 17:391-411. doi: 10.1111/1541-4337.12325

64. Liggins J, Bluck LJ, Runswick S, Atkinson C, Coward WA, Bingham SA. Daidzein and genistein content of fruits and nuts. J Nutr Biochem. (2000) 11:326-31. doi: 10.1016/S0955-2863(00)00085-1

65. Tomé-Carneiro J, Larrosa M, González-Sarrías A, Tomas-Barberan F, Garcia-Conesa M, Carlos EJ. Resveratrol and clinical trials: the crossroad from in vitro studies to human evidence. Curr Pharm Design. (2013) 19:6064-93. doi: 10.2174/13816128113199990407

66. Khurana S, Venkataraman K, Hollingsworth A, Piche M, Tai T. Polyphenols: benefits to the cardiovascular system in health and in aging. Nutrients. (2013) 5:3779-27. doi: 10.3390/nu5103779

67. Kuriyama S, Shimazu T, Ohmori K, Kikuchi N, Nakaya N, Nishino Y, et al. Green tea consumption and mortality due to cardiovascular disease, cancer, and all causes in Japan: the Ohsaki study. JAMA. (2006) 296:1255-65. doi: 10.1001/jama.296.10.1255

68. Meydani M, Hasan ST. Dietary polyphenols and obesity. Nutrients. (2010) 2:737-51. doi: 10.3390/nu2070737

69. Mursu J, Voutilainen S, Nurmi T, Tuomainen TP, Kurl S, Salonen JT. Flavonoid intake and the risk of ischaemic stroke and CVD mortality in middle-aged Finnish men: the Kuopio ischaemic heart disease risk factor study. Br J Nutr. (2008) 100:890-95. doi: 10.1017/S0007114508945694

70. Scalbert A, Manach C, Morand C, Rémésy C, Jiménez L. Dietary polyphenols and the prevention of diseases. Crit Rev Food Sci Nutr. (2005) 45:287-306. doi: $10.1080 / 1040869059096$ 
71. Afshari K, Haddadi NS, Haj-Mirzaian A, Farzaei MH, Rohani MM, Akramian F, et al. Natural flavonoids for the prevention of colon cancer: a comprehensive review of preclinical and clinical studies. J Cell Physiol. (2019) 234:21519-46. doi: 10.1002/jcp.28777

72. Beara IN, Lesjak MM, Orč̌ić DZ, Simin ND, Cětojević-Simin DD, BoŽin $\mathrm{BN}$, et al. Comparative analysis of phenolic profile, antioxidant, antiinflammatory and cytotoxic activity of two closely-related Plantain species: Plantago altissima L. and Plantago lanceolata L. LWT Food Sci Technol. (2012) 47:64-70. doi: 10.1016/j.lwt.2012.01.001

73. Zimmer AR, Leonardi B, Miron D, Schapoval E, deOliveira JR, Gosmann G. Antioxidant and anti-inflammatory properties of Capsicum baccatum: from traditional use to scientific approach. J Ethnopharmacol. (2012) 139:228-33. doi: 10.1016/j.jep.2011.11.005

74. Dos Santos MD, Almeida MC, Lopes NP, DeSouza GEP. Evaluation of the anti-inflammatory, analgesic and antipyretic activities of the natural polyphenol chlorogenic acid. Biol Pharm Bull. (2006) 29:2236-40. doi: $10.1248 / \mathrm{bpb} .29 .2236$

75. Xia D, Wu X, Shi J, Yang Q, Zhang Y. Phenolic compounds from the edible seeds extract of Chinese Mei (Prunus mume Sieb. et Zucc) and their antimicrobial activity. LWT Food Sci Technol. (2011) 44:347-9. doi: 10.1016/j.lwt.2010.05.017

76. Protić D, Radunović N, Spremović-Radenović S, Živanović V, Heinle H, Petrović A, Gojković-Bukarica L. The role of potassium channels in the vasodilatation induced by resveratrol and naringenin in isolated human umbilical vein. Drug Dev Res. (2015) 76:17-23. doi: 10.1002/ddr.21236

77. Gambini J, Inglés $M$, Olaso $G$, Lopez-Grueso $R$, Bonet-Costa V, Gimeno- Mallench L, et al. Properties of resveratrol: in vitro and in vivo studies about metabolism, bioavailability, and biological effects in animal models and humans. Oxidat Med Cell Long. (2015) 2015:837042. doi: $10.1155 / 2015 / 837042$

78. Niedzwiecki A, Roomi MW, Kalinovsky T, Rath M. Anticancer efficacy of polyphenols and their combinations. Nutrients. (2016) 8:552. doi: 10.3390/nu8090552

79. Shim JS, Oh K, Kim HC. Dietary assessment methods in epidemiologic studies. Epidemiol Health. (2014) 36:e2014009. doi: 10.4178/epih/e2014009

80. Del Bo C, Bernardi S, Marino M, Porrini M, Tucci M, Guglielmetti S, et al. Systematic review on polyphenol intake and health outcomes: is there sufficient evidence to define a health-promoting polyphenol-rich dietary pattern? Nutrients. (2019) 11:1355. doi: 10.3390/nu11061355

81. Hein EM, Rose K, van't Slot G, Friedrich AW, Humpf HU. Deconjugation and degradation of flavonol glycosides by pig cecal microbiota characterized by fluorescence in situ hybridization (FISH). J Agric Food Chem. (2008) 56:2281-90. doi: 10.1021/jf073444o

82. Hirooka K, Fujita Y. Excess production of Bacillus subtilis quercetin 2, 3-dioxygenase affects cell viability in the presence of quercetin. Biosci Biotechnol Biochem. (2010) 74:1030-8. doi: 10.1271/bbb.90928

83. Schneider H, Simmering R, Hartmann L, Pforte $H$, Blaut $M$. Degradation of quercetin-3-glucoside in gnotobiotic rats associated with human intestinal bacteria. J Appl Microbiol. (2000) 89:1027-37. doi: 10.1046/j.1365-2672.2000.01209.x

84. Ireson CR, Jones DJ, Orr S, Coughtrie MW, Boocock DJ, Williams ML, et al. Metabolism of the cancer chemopreventive agent curcumin in human and rat intestine. Cancer Epidemiol Prev Biomark. (2002) 11:105-11.

85. Bolca S, Urpi-Sarda M, Blondeel Ph, Roche N, Vanhaecke L, Possemiers S, et al. Disposition of soy isoflavones in normal breast tissue. Am J Clin Nutr. (2010) 91:976-84. doi: 10.3945/ajcn.2009.28854

86. van Dorsten FA, Grün CH, vanVelzen EJJ, Jacobs DM, Draijer R, van Duynhoven JPM. The metabolic fate of red wine and grape juice polyphenols in humans assessed by metabolomics. Mol Nutr Food Res. (2010) 54:897-908. doi: $10.1002 / \mathrm{mnfr} .200900212$

87. Lampe JW. Interindividual differences in response to plant based diets: implications for cancer risk. Am J Clin Nutr. (2009) 89:1553S-57S. doi: 10.3945/ajen.2009.26736D

88. Kemperman RA, Bolca S, Roger LC, Vaughan EE. Novel approaches for analysing 740 gut microbes and dietary polyphenols: challenges and opportunities. Microbiology. (2010) 741:3224-31. doi: $10.1099 /$ mic. $0.042127-0$
89. Sekirov I, Russell SL, Antunes LCM, Finlay BB. Gut microbiota in health and disease. Physiol Rev. (2010) 90:859-904. doi: 10.1152/physrev.00045.2009

90. Eckburg PB, Bik EM, Bernstein CN, Purdom E, Dethlefsen L, Sargent M, et al. Diversity of the human intestinal microbial flora. Science. (2005) 308:1635-8. doi: 10.1126/science.1110591

91. Huttenhower C, Gevers D, Knight R, Abubucker S, Badger JH, Chinwalla AT, et al. Structure, function and diversity of the healthy human microbiome. Nature. (2012) 486:207. doi: 10.1038/nature11234

92. Krishnan S, Alden N, Lee K. Pathways and functions of gut microbiota metabolism impacting host physiology. Curr Opin Biotechnol. (2015) 36:13745. doi: 10.1016/j.copbio.2015.08.015

93. Conlon MA, Bird AR. The impact of diet and lifestyle on gut microbiota and human health. Nutrients. (2014) 7:17-44. doi: 10.3390/nu7010017

94. Yatsunenko T, Rey FE, Manary MJ, Trehan I, Dominguez-Bello MG, Contreras $\mathrm{M}$, et al. Human gut microbiome viewed across age and geography. Nature. (2012) 486:222-7. doi: 10.1038/nature11053

95. An R, Wilms E, Masclee AAM, Smidt H, Zoetendal EG, Jonkers D. Agedependent changes in GI physiology and microbiota: time to reconsider? Gut. (2018) 67:2213-22. doi: 10.1136/gutjnl-2017-315542

96. Claesson MJ, Jeery IB, Conde S, Power SE, O'Connor EM, Cusack S, et al. Gut microbiota composition correlates with diet and health in the elderly. Nature. (2012) 488:178-84. doi: 10.1038/nature11319

97. Pascale A, Marchesi N, Marelli C, Coppola A, Luzi L, Govoni S, et al. Microbiota and metabolic diseases. Endocrine. (2018) 61:357-71. doi: $10.1007 /$ s12020-018-1605-5

98. Zuo T, Ng SC. The gut microbiota in the pathogenesis and therapeutics of inflammatory bowel disease. Front Microbiol. (2018) 9:2247. doi: 10.3389/fmicb.2018.02247

99. Brial F, LeLay A, Dumas ME, Gauguier D. Implication of gut microbiota metabolites in cardiovascular and metabolic diseases. Cell Mol Life Sci. (2018) 75:3977-90. doi: 10.1007/s00018-018-2901-1

100. Fernandes R, Viana SD, Nunes S, Reis F. Diabetic gut microbiota dysbiosis as an inflammaging and immunosenescence condition that fosters progression of retinopathy and nephropathy. Biochim Biophys Acta Mol Basis Dis. (2018) 1865:1876-97. doi: 10.1016/j.bbadis.2018.09.032

101. Ananthakrishnan AN. Epidemiology and risk factors for IBD. Nat Rev Gastroenterol Hepatol. (2015) 12:205-17. doi: 10.1038/nrgastro.2015.34

102. Wedrychowicz A, Zajaç A, Tomasik P. Advances in nutritional therapy in inflammatory bowel diseases: review. World J Gastroenterol. (2016) 22:104566. doi: 10.3748/wjg.v22.i3.1045

103. Evenepoel P, Meijers BK, Bammens BR, Verbeke K. Uremic toxins originating from colonic microbial metabolism. Kidney Int. (2009) 76:S12-9. doi: 10.1038/ki.2009.402

104. Duttona RJ, Turnbaugh PJ. Taking a metagenomic view of human nutrition. Curr Opin Clin Nutr Metab Care. (2012) 15:448-54. doi: 10.1097/MCO.0b013e3283561133

105. Macdonald RS, Wagner K. Influence of dietary phytochemicals and microbiota on colon cancer. J Agric Food Chem. (2012) 60:6728-35. doi: 10.1021/jf204230r

106. Woting A, Clavel T, Loh G, Blaut M. Bacterial transformation of dietary lignans in gnotobiotic rats. FEMS Microbiol Ecol. (2010) 72:507-14. doi: 10.1111/j.1574-6941.2010.00863.x

107. Mabrok HB, Klopfleisch R, Ghanem KZ, Clavel T, Blaut M, Loh G. Lignan transformation by gut bacteria lowers tumor burden in a gnotobiotic rat model of breast cancer. Carcinogenesis. (2012) 33:203-8. doi: 10.1093/carcin/bgr256

108. Namasivayam N. Chemoprevention in experimental animals. Ann N Y Acad Sci. (2011) 1215:60-71. doi: 10.1111/j.1749-6632.2010.05873.x

109. Tulipani S, Urpi-Sarda M, García-Villalba R, Rabassa M, López-Uriarte P, Bullo $\mathrm{M}$, et al. Urolithins are the main urinary microbial-derived phenolic metabolites discriminating a moderate consumption of nuts in free-living subjects with diagnosed metabolic syndrome. J Agric Food Chem. (2012) 60:8930-40. doi: 10.1021/jf301509w

110. Miene C, Weise A, Glei M. Impact of polyphenol metabolites produced by colonic microbiota on expression of COX-2 and GSTT2 in human colon cells (LT97). Nutr Cancer. (2011) 63:653-62. doi: 10.1080/01635581.2011. 552157 
111. Kang NJ, Lee KW, Kim BH, Bode AM, Lee HJ, Heo YS, et al. Coffee phenolic phytochemicals suppress colon cancer metastasis by targeting MEK and TOPK. Carcinogenesis. (2011) 32:921-8. doi: 10.1093/carcin/bgr022

112. McFadden RMT, Larmonier CB, Shehab KW, Midura-Kiela M, Ramalingam $\mathrm{R}$, Harrison CA, et al. The role of curcumin in modulating colonic microbiota during colitis and colon cancer prevention. Inflamm Bowel Dis. (2015) 21:2483-94. doi: 10.1097/MIB.0000000000000522

113. Monagas M, Khan N, Andres-Lacueva C, Urpi-Sarda M, Vázquez-Agell M, Lamuela-Raventos RM, et al. Dihydroxylated phenolic acids derived from microbial metabolism reduce lipopolysaccharide-stimulated cytokine secretion by human peripheral blood mononuclear cells. Br J Nutr. (2009) 102:201-6. doi: 10.1017/S0007114508162110

114. Larrosa M, Luceri C, Vivoli E, Pagliuca C, Lodovici M, Moneti G, et al. Polyphenol metabolites from colonic microbiota exert anti-inflammatory activity on different inflammation models. Mol Nutr Food Res. (2009) 53:1044-54. doi: 10.1002/mnfr.200800446

115. Tucsek Z, Radnai B, Racz B, Debreceni B, Priber JK, Dolowschiak T, et al. Suppressing LPS-induced early signal transduction in macrophages by a polyphenol degradation product: a critical role of MKP-1. J Leukoc Biol. (2011) 89:105-11. doi: 10.1189/jlb.0610355

116. Beloborodova N, Bairamov I, Olenin A, Shubina V, Teplova V, Fedotcheva $\mathrm{N}$. Effect of phenolic acids of microbial origin on production of reactive oxygen species in mitochondria and neutrophils. J Biomed Sci. (2012) 19:89. doi: 10.1186/1423-0127-19-89

117. Sharma S, Chopra K, Kulkarni S, Agrewala J. Resveratrol and curcumin suppress immune response through CD28/CTLA-4 and CD80 co-stimulatory pathway. Clin Exp Immunol. (2007) 147:155-63. doi: 10.1111/j.1365-2249.2006.03257.x

118. Kumar Singh A, Cabral C, Kumar R, Ganguly R, Kumar Rana H, Gupta A, et al. Beneficial effects of dietary polyphenols on gut microbiota and strategies to improve delivery efficiency. Nutrients. (2019) 11:2216. doi: 10.3390/nu11092216

119. Stapleton PD, Shah S, Ehlert K, Hara Y, Taylor PW. The betalactam-resistance modifier (-)-epicatechin gallate alters the architecture of the cell wall of Staphylococcus aureus. Microbiology. (2007) 153:2093. doi: 10.1099/mic. $0.2007 / 007807-0$

120. Tombola F, Campello S, De Luca L, Ruggiero P, Del Giudice G, Papini E, et al. Plant polyphenols inhibit VacA, a toxin secreted by the gastric pathogen Helicobacter pylori. FEBS Lett. (2003) 543:184-9. doi: 10.1016/S0014-5793(03)00443-5

121. Chan CL, Gan RY, Shah NP, Corke H. Polyphenols from selected dietary spices and medicinal herbs differentially affect common food-borne pathogenic bacteria and lactic acid bacteria. Food Control. (2018) 92:437-43. doi: 10.1016/j.foodcont.2018.05.032

122. Romier BYJ. Larondelle SY, During A. Dietary polyphenols can modulate the intestinal inflammatory response. Nutr Rev. (2009) 67:363-78. doi: 10.1111/j.1753-4887.2009.00210.x

123. Sergent TN, Meurice PJ, Toussaint O, Schneider YJ. Anti-inflammatory effects of dietary phenolic compounds in an in vitro model of inflamed human intestinal epithelium. Chem Biol Interact. (2010) 188 (3):659-67. doi: 10.1016/j.cbi.2010.08.007

124. Nicod N, Chiva-Blanch G, Giordano E, Davalos A, Parker RS, Visioli F. Green tea, cocoa, and red wine polyphenols moderately modulate intestinal inflammation and do not increase high-density lipoprotein (HDL) production. J Agric Food Chem. (2014) 62:2228-32. doi: 10.1021/jf500348u

125. Romier-Crouzet B, Van De Walle J, During A, Joly A, Rousseau C, Henry O, et al. Inhibition of inflammatory mediators by polyphenolic plant extracts in human intestinal Caco-2 cells. Food Chem Toxicol. (2009) 47:1221-30. doi: 10.1016/j.fct.2009.02.015

126. Lee JS, Park SY, Thapa D, Choi MK, Chung IM, Park YJ, et al. Grifola frondosa water extract alleviates intestinal inflammation by suppressing TNF-a production and its signaling. Exp Mol Med. (2010) 42:143-54. doi: $10.3858 / \mathrm{emm} .2010 .42 .2 .016$

127. Biasi F, Guina T, Maina M, Cabboi B, Deiana M, Tuberoso CI, et al. Phenolic compounds present in Sardinian wine extracts protect against the production of inflammatory cytokines induced by oxysterols in CaCo2 human enterocyte-like cells. Biochem Pharmacol. (2013) 86:138-45. doi: 10.1016/j.bcp.2013.03.024
128. During A, Debouche C, Raas T, Larondelle Y. Among plant lignans, pinoresinol has the strongest antiinflammatory properties in human intestinal Caco-2 cells. J Nutr. (2012) 142:1798-805. doi: $10.3945 /$ jn.112.162453

129. Sengottuvelan M, Nalini N. Dietary supplementation of resveratrol suppresses colonic tumour incidence in 1,2-dimethylhydrazine-treated rats by modulating biotransforming enzymes and aberrant crypt foci development. Br J Nutr. (2006) 96:145-53. doi: 10.1079/BJN20061789

130. Sanchez-Fidalgo S, Cardeno A, Villegas I, Talero E, de la Lastra CA. Dietary supplementation of resveratrol attenuates chronic colonic inflammation in mice. Eur J Pharmacol. (2010) 633:78-84. doi: 10.1016/j.ejphar.2010.01.025

131. Martin AR, Villegas I, La Casa C, de la Lastra CA. Resveratrol, a polyphenol found in grapes, suppresses oxidative damage and stimulates apoptosis during early colonic inflammation in rats. Biochem Pharmacol. (2004) 67:1399-410. doi: 10.1016/j.bcp.2003.12.024

132. Singh UP, SinghNP, Singh B, Hofseth LJ, Price RL, Nagarkatti M, et al. Resveratrol (trans-3,5,4'-trihydroxystilbene) induces silent mating type information regulation-1 and down-regulates nuclear transcription factorkappaB activation to abrogate dextran sulfate sodium-induced colitis. $J$ Pharmacol Exp Ther. (2010) 332:829-39. doi: 10.1124/jpet.109.160838

133. Etxeberria U, Arias N, Boqué N, Macarulla M, Portillo M, Martinez J, et al. Reshaping faecal gut microbiota composition by the intake of transresveratrol and quercetin in high-fat sucrose diet-fed rats. J Nutr Biochem. (2015) 26:651-60. doi: 10.1016/j.jnutbio.2015.01.002

134. Isabel V, Susana SF, Alarcon DLLC. Chemopreventive effect of dietary curcumin on inflammationinduced colorectal carcinogenesis in mice. Mol Nutr Food Res. (2011) 55:259-67. doi: 10.1002/mnfr.201000225

135. Ruan Z, Liu S, Zhou Y, Mi S, Liu G, Wu X, et al. Chlorogenic acid decreases intestinal permeability and increases expression of intestinal tight junction proteins in weaned rats challenged with LPS. PLoS ONE. (2014) 9:e97815. doi: 10.1371/journal.pone.0097815

136. Rosillo MA, Sanchez-Hidalgo M, Cardeno A, Alarcon de la Lastra C. Protective effect of ellagic acid, a natural polyphenolic compound, in a murine model of Crohn's disease. Biochem Pharmacol. (2011) 82:737-45. doi: 10.1016/j.bcp.2011.06.043

137. Syed U, Ganapasam S. Differential inhibitory effects of the polyphenol ellagic acid on inflammatory mediators NF-kappaB, iNOS, COX-2, TNF-alpha, and IL-6 in 1,2-dimethylhydrazineinduced rat colon carcinogenesis. Basic Clin Pharmacol Toxicol. (2010) 107:650-5. doi: 10.1111/j.1742-7843.2010.00565.x

138. Okazaki Y, HanY, Kayahara M, Watanabe T, Arishige H, Kato N. Consumption of curcumin elevates fecal immunoglobulin $\mathrm{A}$, an index of intestinal immune function, in rats fed a high-fat diet. J Nutr Sci Vitaminol. (2010) 56:68-71. doi: 10.3177/jnsv.56.68

139. Dolara P, Luceri C, De Filippo C, Femia AP, Giovannelli L, Caderni $G$, et al. Red wine polyphenols influence carcinogenesis, intestinal microflora, oxidative damage and gene expression profiles of colonic mucosa in F344 rats. Mutat Res Mol Mech Mutagen. (2005) 591:237-46. doi: 10.1016/j.mrfmmm.2005.04.022

140. Varilek GW, Yang F, Lee EY, deVilliers WJS, Zhong J, Oz HS, et al. Green tea polyphenol extract attenuates inflammation in interleukin-2deficient mice, a model of autoimmunity. J Nutr. (2001) 131:2034-9. doi: 10.1093/jn/131.7.2034

141. Lin G, Yan X, Liu D, Yang C, Huang Y, Zhao C. Role of green macroalgae enteromorpha prolifera polyphenols in the modulation of gene expression and intestinal microflora profiles in type 2 diabetic mice. Int J Mol Sci. (2019) 20:25. doi: $10.3390 /$ ijms 20010025

142. Pandurangan AK, Mohebali N, Mohd N, Esa C, Y Looi Y, Ismail S, et al. Gallic acid suppresses inflammation in dextran sodium sulfate-induced colitis in mice: Possible mechanisms. Int Immunopharmacol. (2015) 28:1034-43. doi: 10.1016/j.intimp.2015.08.019

143. Canali R, Vignolini F, Nobili F, Mengheri E. Reduction of oxidative stress and cytokine-induced neutrophil chemoattractant (CINC) expression by red wine polyphenols in zinc deficiency induced intestinal damage of rat. Free Radic Biol Med. (2000) 28:1661-70. doi: 10.1016/S0891-5849(00)00285-9

144. Wang K, Jin X, Li Q, Sawaya ACHF, Le Leu RK, Conlon MA, et al. Propolis from different geographic origins decreases intestinal inflammation and Bacteroides spp. Populations in a Model of DSS-Induced Colitis. Mol Nutr Food Res. (2018) 62:e1800080. doi: 10.1002/mnfr.201800080 
145. Kim YH, Kwon HS, Kim DH, Cho HJ, Lee HS, Jun JG, et al. Piceatannol, a stilbene present in grapes, attenuates dextran sulfate sodium-induced colitis. Int Immunopharmacol. (2008) 8:1695-702. doi: 10.1016/j.intimp.2008.08.003

146. Massot-Cladera M, Abril-Gil M, Torres S, Franch A, Castell M, PerezCano FJ. Impact of cocoa polyphenol extracts on the immune system and microbiota in two strains of young rats. Br J Nutr. (2014) 112:1944-54. doi: 10.1017/S0007114514003080

147. Perez-Berezo T, Franch A, Castellote C, Castell M, Perez-Cano FJ. Mechanisms involved in down-regulation of intestinal IgA in rats by high cocoa intake. J Nutr Biochem. (2012) 23:838-44. doi: 10.1016/j.jnutbio.2011.04.008

148. Wang K, Wan Z, Ou A, Liang X, Guo X, Zhang Z, et al. Monofloral honey from a medical plant, Prunella Vulgaris, protected against dextran sulfate sodium-induced ulcerative colitis via modulating gut microbial populations in rats. Food Funct. (2019) 10:3828-38. doi: 10.1039/C9FO00460B

149. Kim H, Banerjee N, Barnes RC, Pfent CM, Talcott ST, Dashwood RH, et al. Mango polyphenolics reduce inflammation in intestinal colitisinvolvement of the miR-126/PI3K/AKT/mTOR axis in vitro and in vivo. Mol Carcinog. (2017) 56:197-207. doi: 10.1002/mc.22484

150. Taira T, Yamaguchi S, Takahashi A, Okazaki Y, Yamaguchi A, Sakaguchi H, et al. Dietary polyphenols increase fecal mucin and immunoglobulin A and ameliorate the disturbance in gut microbiota caused by a high fat diet. J Clin Biochem Nutr. (2015) 57:212-6. doi: 10.3164/jcbn.15-15

151. Zanzer YC, Plaza M, Dougkas A, Turner C, Björck I, Östman E. Polyphenol-rich spice-based beverages modulated postprandial early glycaemia, appetite and PYY after breakfast challenge in healthy subjects: a randomised, single blind, crossover study. J Funct Food. (2017) 35:574-83. doi: 10.1016/j.jff.2017.06.016

152. Snopek L, Mlcek J, Sochorova L, Baron M, Hlavacova I, Jurikova T, et al. Contribution of redwine consumption to human health protection. Molecules. (2018) 23:1684. doi: 10.3390/molecules23071684

153. Rastmanesh R. High polyphenol, low probiotic diet for weight loss because of intestinal microbiota interaction. Chem Interact. (2011) 189:1-8. doi: 10.1016/j.cbi.2010.10.002

154. Limagne E, Thibaudin M, Euvrard R, Berger H, Chalons P, Végan F, et al. Sirtuin-1 activation controls tumor growth by impeding Th17 differentiation via STAT3 deacetylation. Cell Rep. (2017) 19:746-59. doi: 10.1016/j.celrep.2017.04.004
155. Zhang Z, Wu X, Cao S, Cromie M, Shen Y, Feng Y, et al. Chlorogenic acid ameliorates experimental colitis by promoting growth of Akkermansia inmice. Nutrients. (2017) 9:677. doi: 10.3390/nu9070677

156. Ahn SC, Kim GY, Kim JH, Baik SW, Han MK, Lee HJ, et al. Epigallocatechin3-gallate, constituent of green tea, suppresses the LPS-induced phenotypic and functional maturation of murine dendritic cells through inhibition of mitogen-activated protein kinases and NF-кB. Biochem Biophys Res Commun. (2004) 313:148-55. doi: 10.1016/j.bbrc.2003.11.108

157. Kim GY, Kim KH, Lee SH, Yoon MS, Lee HJ, Moon DO, et al Curcumin inhibits immunostimulatory function of dendritic cells: MAPKs and translocation of NF-kB as potential targets. J Immunol. (2005) 174:811624. doi: 10.4049/jimmunol.174.12.8116

158. Kotla NG, Rana S, Sivaraman G, Sunnapu O, Vemula PK, Pandit A, et al. Bioresponsive drug delivery systems in intestinal inflammation: state-ofthe-art and future perspectives. Adv Drug Deliv Rev. (2019) 146:248-66. doi: 10.1016/j.addr.2018.06.021

159. Chung JH, Lee SJ, Chung JO, Oh YJ, Hwang JA, Kim YK, et al. Effect of hydroxypropyl methyl cellulose phthalate coating on digestive stability and intestinal transport of green tea catechins. Integr Med Res. (2014) 3:34-7. doi: 10.1016/j.imr.2013.11.001

160. Xiao B, Si X, Zhang M, Merlin D. Oral administration of pH-sensitive curcumin-loaded microparticles for ulcerative colitis therapy. Colloids Surf B Biointerfaces. (2015) 135:379-85. doi: 10.1016/j.colsurfb.2015.07.081

161. Lozano-Perez AA, Rodriguez-Nogales A, Ortiz-Cullera V, Algieri F, Garrido-Mesa J, Zorrilla P, et al. Silk fibroin nanoparticles constitute a vector for controlled release of resveratrol in an experimental model of inflammatory bowel disease in rats. Int J Nanomed. (2014) 9:4507-20. doi: $10.2147 /$ IJN.S68526

Conflict of Interest: The authors declare that the research was conducted in the absence of any commercial or financial relationships that could be construed as a potential conflict of interest.

Copyright (๑) 2021 Ray and Mukherjee. This is an open-access article distributed under the terms of the Creative Commons Attribution License (CC BY). The use, distribution or reproduction in other forums is permitted, provided the original author(s) and the copyright owner(s) are credited and that the original publication in this journal is cited, in accordance with accepted academic practice. No use, distribution or reproduction is permitted which does not comply with these terms. 